\title{
Astrapotheres from Cañadón Vaca, middle Eocene of central Patagonia. New insights on diversity, anatomy, and early evolution of Astrapotheria
}

\author{
Alejandro G. Kramarz, Mariano Bond, and Alfredo A. Carlini
}

\begin{abstract}
Astrapotheria is one of the most emblematic groups of endemic South American ungulate-like extinct mammals, traditionally compared with modern tapirs and rhinos. Oldest astrapotheres are known from the early Eocene Itaboraian fauna (Brazil), but the earliest diverse astrapothere assemblage is known from the middle Eocene Cañadón Vaca Member of the Sarmiento Formation exposed at Cañadón Vaca (Vacan subage of the Casamayoran Land Mammal Age), in central Patagonia, Argentina. Previous reports of astrapotheres from Cañadón Vaca included Trigonostylops, Tetragonostylops, Albertogaudrya, and Scaglia, but only the record of the latter was unequivocal. New materials from Cañadón Vaca described herein confirms the occurrence of Trigonostylops ( $T$. wortmani) and of Tetragonostylops (likely represented by a species different from the nominal species from Itaboraí). Additionally, two other taxa are identified: the former, described as cf. Scaglia cf. kraglievichorum, is represented by a partial skull with an unusual combination of cranial characters, and could correspond to an adult of Scaglia kraglievichorum (known by a juvenile skull); the other taxon is represented by a partial mandible with distinctive osteological and dental features, but the possibility of its belonging to Scaglia cannot be discarded. The occurrence of Albertogaudrya in Cañadón Vaca could not be confirmed by the examination of the new and previous collections. Astrapotheres from Cañadón Vaca show a wide morphological disparity of cranial designs, but all consistently share long, unreduced nasals, thus the presumed possession of a short tapir-like proboscis only typifies the post-Casamayoran astrapotheres.
\end{abstract}

Alejandro G. Kramarz. Consejo Nacional de Investigaciones Científicas y Técnicas (CONICET), Sección Paleontología de Vertebrados, Museo Argentino de Ciencias Naturales Bernardino Rivadavia, Av. Ángel Gallardo 470, C1405DJR, Ciudad Autónoma de Buenos Aires, Argentina. agkramarz@macn.gov.ar Mariano Bond. Consejo Nacional de Investigaciones Científicas y Técnicas (CONICET); Departamento

Kramarz, Alejandro G., Bond, Mariano, and Carlini, Alfredo A. 2019. Astrapotheres from Cañadón Vaca, middle Eocene of central Patagonia. New insights on diversity, anatomy, and early evolution of Astrapotheria. Palaeontologia Electronica 22.2.52A 1-22. https://doi.org/10.26879/986

palaeo-electronica.org/content/2019/2688-canadon-vaca-astrapotheres

Copyright: August 2019 Paleontological Society.

This is an open access article distributed under the terms of Attribution-NonCommercial-ShareAlike 4.0 International (CC BY-NC-SA 4.0 ), which permits users to copy and redistribute the material in any medium or format, provided it is not used for commercial purposes and the original author and source are credited, with indications if any changes are made.

creativecommons.org/licenses/by-nc-sa/4.0/ 
Científico Paleontología de Vertebrados, Museo de La Plata, Paseo del Bosque s/n, La Plata B1900FWA, Provincia de Buenos Aires, Argentina. constantino1453@yahoo.com.ar

Alfredo A. Carlini. Consejo Nacional de Investigaciones Científicas y Técnicas (CONICET); Laboratorio de Morfología Evolutiva y Desarrollo (MORPHOS), and División Paleontología Vertebrados, Museo de La Plata, Fac. Cs. Naturales y Museo, UNLP. Paseo del Bosque s/n, La Plata B1900FWA, Provincia de Buenos Aires, Argentina. acarlini@fcnym.unlp.edu.ar

Keywords: Astrapotheria; systematics; Sarmiento Formation; Eocene; Cañadón Vaca; Patagonia

Submission: 28 March 2019. Acceptance: 30 July 2019.

\section{INTRODUCTION}

Astrapotheres are extinct South American placental mammals, possibly derived from an early panperissodactyl radiation that gave origin to litopterns and notoungulates (Soria, 1988; Billet, 2010; Muizon et al., 2015; Welker et al., 2015). These enigmatic mammals are characterized by having enlarged canines and rhino-like cheek teeth. At least the late diverging forms, were enormous herbivorous with several tarsal adaptations associated with graviportal habits, and exhibited strongly retracted nasals suggesting the presence of a short, tapir-like proboscis (Ameghino 1894; Scott 1937; Cifelli, 1983; Johnson and Madden, 1997; Kramarz and Bond, 2009). Earliest undisputable astrapotheres are recorded in the early Eocene Itaboraí fauna in east Brazil, represented by a single nominal species Tetragonostylops apthomasi (Price and Paula-Couto, 1950), and in the Kibenikhoria Faunal Zone of Las Flores Formation, represented by an edentulous mandibular fragment described as Shecenia ctirneru (Simpson, $1935 a$ and b). The earliest multi-specific assemblage of this clade is derived from the lower section of the Sarmiento Formation at Cañadón Vaca, in central Patagonia (the Cañadón Vaca Member, Bellosi and Krause, 2014). In addition to the astrapotheres, the Cañadón Vaca Member of the Sarmiento Formation exposed at Cañadón Vaca yielded a wide diversity of metatherian and placental mammals (22 species grouped in 19 genera, Cifelli, 1985). They form a distinct mammal assemblage, which is the basis of the Vacan subAge of the Casamayoran Land Mammal Age (Cifelli, 1985). The Vacan sub-Age together with to the Barrancan sub-Age constitute the Casamayoran South American Land Mammal Age (Cifelli, 1985).

The deposits bearing Vacan mammals are dated in $43 \mathrm{Ma}$ (Lutetian, middle Eocene, Dunn et al., 2015). Among South American Cenozoic fossil mammal localities, Cañadón Vaca is one of the old- est yielding very abundant, well-preserved cranial and mandibular remains, some associated with postcranial elements (Carrillo and Asher, 2017). Thus, mammals from Cañadón Vaca are crucial for the understanding of the early stages of diversification of most South American native mammals.

It is traditionally accepted that four astrapothere taxa co-occur in these vertebrate-bearing deposits: Scaglia kraglievichorum, Trigonostylops wortmani, aff. Tetragonostylops apthomasi, and an indeterminate species of Albertogaudrya (Simpson, 1957, 1967; Soria, 1982; Cifelli, 1985; Kramarz and Bond, 2013; Woodburne et al., 2014). Nevertheless, the inventory numbers or identifications of specimens substantiating the occurrence of Trigonostylops and Albertogaudrya were never provided in the literature. The occurrence of Tetragonostylops is supported by a single molar (Soria, 1982), but its generic assignment has not been discussed exhaustively. Consequently, only the occurrence of Scaglia kraglievichorum, described upon a partial juvenile skull from Cañadón Vaca (Simpson, 1957), is unequivocal. We herein describe new astrapothere materials derived from the Vacan faunal unit of the Cañadón Vaca Member at Cañadón Vaca, and compare with other materials previously described from this and other Eocene faunas. These new findings provide a new insight on the astrapothere taxonomic diversity and morphological disparity during the Vacan times and on early diversification of this emblematic South American placental clade.

\section{Institutional Abbreviations}

AMNH, American Museum of Natural History (New York, USA); DGM, Divisao de Geologia e Mineralogia do Departamento Nacional da Producao Mineral (Brazil); MACN, Museo Argentino de Ciencias Naturales Bernardino Rivadavia; MLP, Museo de La Plata (Argentina); MMP, Museo Municipal de Ciencias Naturales Lorenzo Scaglia (Mar del Plata, Argentina); MNRJ, Museu Nacional do Rio de 
Janeiro (Brazil); MPEF PV, Museo Paleontológico Egidio Feruglio (Chubut Province, Argentina), paleovertebrate collection.

\section{Anatomical Abbreviations}

$\mathrm{i}$, lower incisor; C/c, upper/lower canine; P/p, upper/lower premolar; $\mathrm{M} / \mathrm{m}$, upper/lower molar.

\section{GEOLOGICAL SETTING}

Cañadón Vaca is a tributary to the left (northwest) bank of the Río Chico, approximately $60 \mathrm{~km}$ northeast of the Gran Barranca South of Colhue Huapi Lake (Cifelli, 1985), in East-central Patagonia (see Figure 1). The Sarmiento Formation is exposed on the north side of the Cañadón, at the Southern slope of the Pampa Pelada, where it is represented by $115 \mathrm{~m}$ thick of continental pyroclastic deposits overlying the Las Flores Formation, and covered by Quaternary deposits. The lower 55 $\mathrm{m}$ correspond to the Cañadón Vaca Member (Bellosi and Krause, 2014), mainly constituted by yellowish gray pyroclastic and siliciclastic mudstones, fine tuffs, conglomerates and paleosols. It differs from the overlying Gran Barranca Member in having conglomerates and coarse-grained sandstones, more abundant siliciclastic mudstones and tuffs, and less frequent and poorly developed paleosoils (Bellosi and Krause, 2014). Cifelli (1985) identified five fossiliferous sites within the Cañadón Vaca Member, of which the four located in the lower $20 \mathrm{~m}$ of the sequence produced almost the whole Vacan fossil sample, including the more complete and better preserved specimens. The MPEF specimens herein described were unearthed from a pyroclastic mudstone located 10 $\mathrm{m}$ above the base of the exposed section at $45^{\circ}$ $12^{\prime} 13.9^{\prime \prime} \mathrm{S}, 68^{\circ} 07^{\prime} 18.3^{\prime \prime} \mathrm{W}$. This horizon is the one identified by Cifelli (1985: fig. 8, Cañadón Vaca Section I) as the fossiliferous site 1, which yielded the largest Vacan mammal diversity. The specimen AMNH 28450 (Simpson, 1930) also derives from this horizon. The exact stratigraphic provenance of the juvenile skull (MMP M-207), type of Scaglia kraglievichorum, is uncertain, but very likely derives from some of the lowermost levels of the section, which yielded the more complete specimen. Similarly, the isolated molar MACN Pv $\mathrm{CH} 1248$ reported by Soria (1982) as coming from the Casamayoran of Cañadón Vaca has not an exact stratigraphic provenance, although the associated materials strongly suggest that it derives from some of the lower levels.

\section{SYSTEMATIC PALEONTOLOGY}

Order ASTRAPOTHERIA Lydekker, 1894

Family ASTRAPOTHERIIDAE Ameghino, 1887

Genus TETRAGONOSTYLOPS Paula-Couto, 1963

Tetragonostylops aff. T. apthomasi (Price and Paula-Couto, 1950)

Figure 2.1-6

Material. MPEF PV 5479, a partial skull preserving part of the right side of the rostrum, orbit, and zygomatic arch, most of the skull roof, base of the right

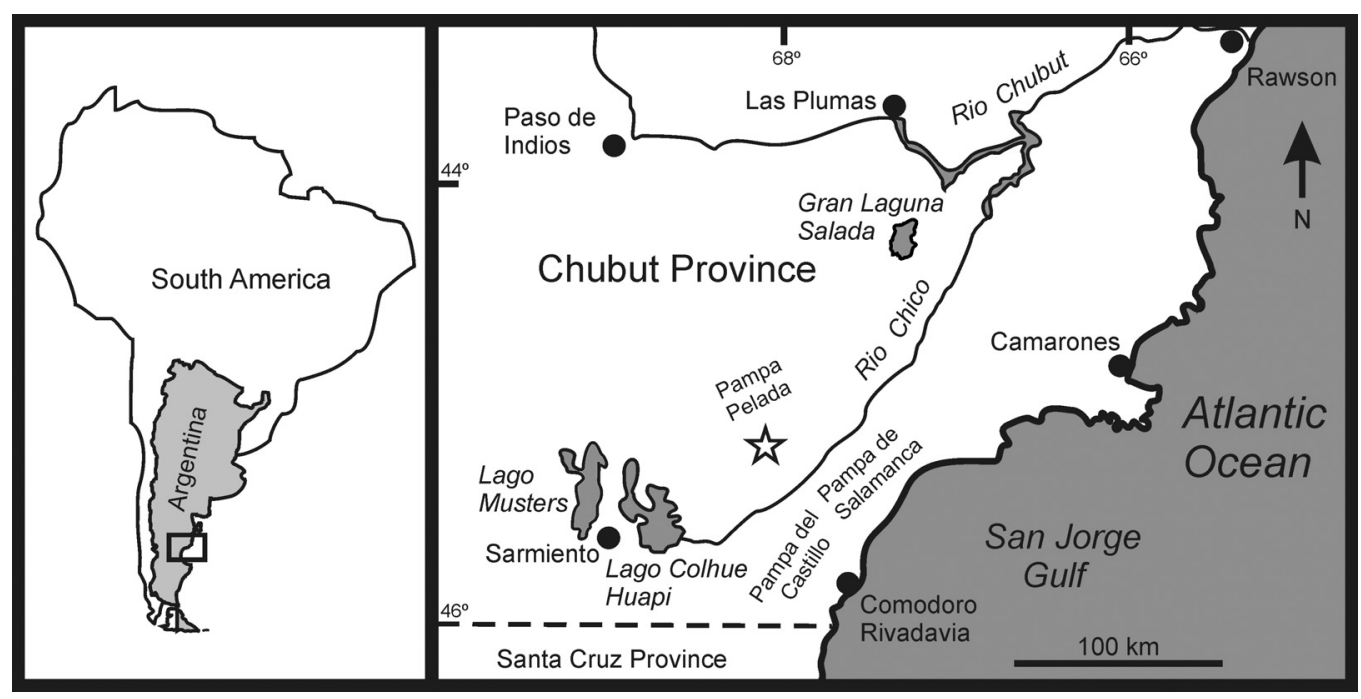

FIGURE 1. Map showing the geographic location of Cañadón Vaca fossil locality (white star) in Chubut province, Argentina, and other geographic references mentioned in the text. 

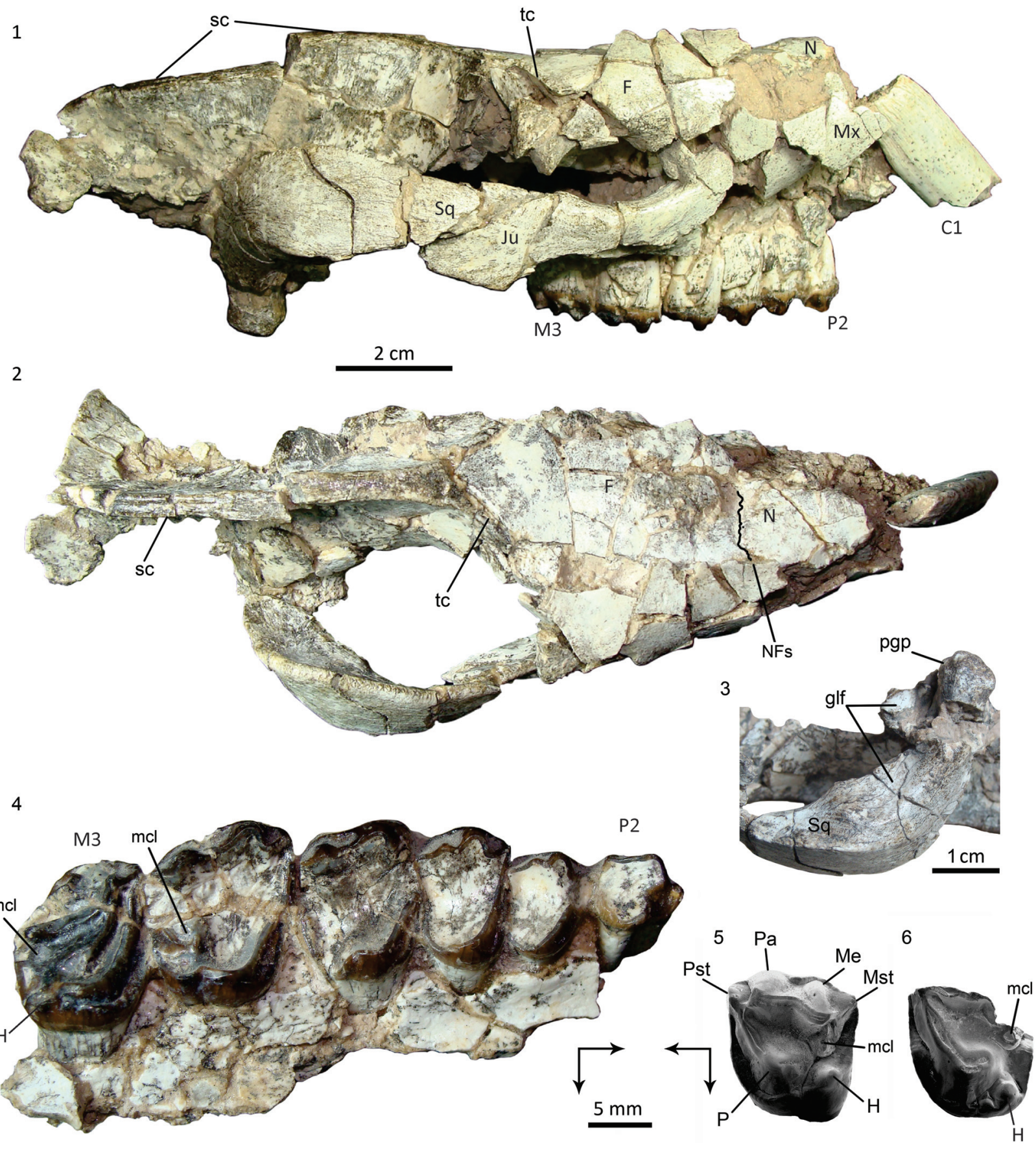

FIGURE 2. Tetragonostylops aff. T. apthomasi (Price and Paula-Couto, 1950). 1, MPEF PV 5479, partial skull in lateral view; 2 , idem, in dorsal view; 3 , idem, detail of the glenoid surface, in ventrolateral view; 4 , idem, right cheek teeth series in occlusal view; 5, MACN Pv CH1248, left M1 or M2 in occlusal view; 6, MPEF PV 5481, partial left M3, in occlusal view. Abbreviations: $\mathrm{F}=$ frontal, glf=glenoid fossa, $\mathrm{H}=$ hypocone, $\mathrm{Ju}=\mathrm{jugal}, \mathrm{mcl}=$ metaconule; $\mathrm{Me}=\mathrm{metacone}$, Mst=mesostyle, $\mathrm{Mx}=$ =maxillary, $\mathrm{N}=$ nasal, $\mathrm{NFs}=$ naso-frontal suture (remarked), $\mathrm{P}=$ protocone, $\mathrm{Pa}=$ paracone, $\mathrm{pgp}=$ postglenoid process, $\mathrm{Pst}=$ parastyle, $\mathrm{sc}=$ sagittal crest, $\mathrm{Sq}=$ =squamosal, tc=temporal crest. Arrows indicate mesial and lingual sides. 
canine and right maxillary with P2-M3 (Figure 2.14); MPEF PV 5480, an isolated M1 or M2; MACN $\mathrm{Pv} \mathrm{CH} 1248$, isolated $\mathrm{M} 1$ or M2 (Figure 2.5) (reported as MACN CH 417 by Soria, 1982); MPEF PV 5481, partial left M3 (Figure 2.6), AMNH 28450, isolated M3 (Simpson, 1967, figure 49).

Description and comparisons. Most of the preserved parts of the skull MPEF PV 5479 are severely fractured and distorted, with many separated bone fragments still supported by the matrix, roughly in their original position in the skull (Figure 2.1-2). Based on the current disposition of the fragments, the rostrum seems to have been tubular, although narrower anteriorly. The anterior end of the right nasal is missing; the preserved portion forms most of the roof of the rostrum and reaches the level of the P4; the suture with the frontal is nearly transverse and located at the level of the anterior margin of the orbit (Figure 2.1-2). Consequently, there is no evidence of nasal reduction and/or retraction that typifies all the post-Casamayoran astrapotheres. The frontals are very wide, mostly flat on the midline but very convex laterally (although emphasized by the post mortem distortion), forming a large supraorbital roof that ends in a robust postorbital process. The postorbital constriction of the frontal is very marked, thus the posterior margin of the supraorbital roof is almost transverse, at least in the more laterally preserved part, and becomes gradually oblique near the midline forming a short temporal crest. The crests of both sides converge on the midline, where the frontals wedge between the parietals and form a sharp sagittal crest (Figure 2.2). This area of the skull roof resembles particularly that of the DGM 310-M from Itaboraí, referred to Tetragonostylops apthomasi by Paula-Couto (1963). Contrarily, in Trigonostylops (see Appendix 1), the temporal crests are much longer and less transverse, and the frontals are domed (the postorbital process is incomplete in the only known complete skull). The sagittal crest of MPEF PV 5479, mostly formed by the parietals, is very high and long (almost half of the preserved length of the skull). In lateral view (Figure 2.1), the sagittal crest describes a slight curve, being higher at the level of the glenoid cavity. A small preserved portion of the supraoccipital reveals the presence of a very elevated and nearly transverse lambdoid crest continue with the sagittal crest. The morphology of the posterior portion of the skull roof agrees well with that known for Trigonostylops (AMNH 28700).

Only few cracked fragments of the facial process of the maxillary were preserved, and no sig- nificant features of the lateral rostrum can be observed (e.g., sutures, foramina). The base of the zygomatic process of the maxillary is roughly lateral to the $M 2$, although the anterior border is not preserved. The anterior root of the zygoma does not protrude much laterally, but it gently diverges from the lateral wall of the rostrum (Figure 2.2), although this condition could be accentuated by the distortion suffered by the specimen. The zygomatic arch is robust, moderately high, nearly equally built by the jugal and the squamosal. The jugal forms the entire anteroventral rim of the orbit. The frontal (post-orbital) process of the jugal is represented by a very slight elevation of the dorsal contour of the jugal, just below the postorbital process of the frontal (Figure 2.1). The outline of the orbit is deformed by the dorso-ventral distortion, although judging by the dorsal profile of the jugal, it would have been moderately large, as in Trigonostylops. The zygomatic process of the squamosal is somewhat tilted against the braincase, and thus it seems very raised seen in lateral view. In its original position, the squamosal contribution to the zygoma would have been slightly raised posteriorly, since the posterior root of the zygoma is roughly at the same level as the anterior root (Figure 2.1). The postglenoid process is blunt, hemispherical, nearly as wide as long (Figure 2.1, 2.3), and much narrower than in Trigonostylops. A very minute portion of the glenoid cavity is preserved in front of the process, but it continues anteriorly with a large, nearly flat surface on the ventral aspect of the zygomatic arch (Figure 2.3), likely for insertion of the zygomatico-mandibularis muscle, as in Astrapotherium. This surface is bounded posterolaterally by a sharp crest, which connects anteriorly with the squamosal-jugal suture on the lateral aspect of the zygomatic arch; posteriorly, the crest becomes inconspicuous and does not join the base of the postglenoid process.

Only the root of the canine is preserved, still supported by the sediment in its approximate, but not exactly, original location, although the alveolus is entirely missing (Figure 2.1-2). The base of the canine is ovoid in cross section, much larger mesiodistally, and more convex labially than lingually. The major axis is nearly as long as the P2P3 length, thus proportionally as large as in Tetragonostylops apthomasi (DGM 355M). No maxillary fragment is preserved in front the P2, which has no trace of facet for an anterior tooth; therefore, the P1 (if present) would have been separated from the subsequent premolar. The P2-M3 (Figure 2.4) are arranged in a closed series. 
TABLE 1. Dental measurements (in $\mathrm{mm}$ ) of Tetragonostylops aff. T. apthomasi from Cañadón Vaca compared with Tetragonostylops apthomasi from Itaboraí. Measurements of Itaboraí specimens taken from Paula Couto (1952). Abbreviations: mdl, maximum distolabial length; trw, transverse width. * denotes approximate measurement.

\begin{tabular}{|c|c|c|c|c|c|c|c|c|c|c|c|c|c|c|c|}
\hline \multirow[b]{2}{*}{ Taxon } & \multirow[b]{2}{*}{ Specimen } & \multicolumn{2}{|c|}{ C1 } & \multicolumn{2}{|c|}{ P2 } & \multicolumn{2}{|c|}{ P3 } & \multicolumn{2}{|c|}{ P4 } & \multicolumn{2}{|c|}{ M1 } & \multicolumn{2}{|c|}{ M2 } & \multicolumn{2}{|c|}{ M3 } \\
\hline & & mdl & trw & mdl & trw & mdl & trw & mdl & trw & mdl & trw & mdl & trw & mdl & trw \\
\hline \multirow{3}{*}{$\begin{array}{l}\text { Tetragonostylops } \\
\text { aff. } T \text {. apthomasi } \\
\text { from Cañadón } \\
\text { Vaca }\end{array}$} & MPEF PV 5479 & 14.3 & 7.9 & 8.1 & 7.7 & 8.2 & 9.9 & 8.5 & 12.9 & 10.3 & 14 & 13 & $16.5^{*}$ & $13.2^{*}$ & $16.8^{*}$ \\
\hline & MACN Pv CH1248 & & & & & & & & & 10.8 & 12.6 & & & & \\
\hline & AMNH 28450 & & & & & & & & & & & & & 12.5 & 18 \\
\hline \multirow{4}{*}{$\begin{array}{l}\text { Tetragonostylops } \\
\text { apthomasi from } \\
\text { Itaboraí }\end{array}$} & DGM 355-M & & & 6.6 & 4.3 & 7 & 8.2 & 7 & 10.5 & 10 & 11.9 & 12 & 13.8 & 11.2 & 14 \\
\hline & DGM 287-M & & & & & & & & & 9.2 & 10.5 & 11 & 13 & & \\
\hline & MNRJ 1830-V & & & & & & & & & & & 12 & 13.8 & 12 & 15.2 \\
\hline & MNRJ 1829-V & & & & & & & & & & & $12^{*}$ & $13^{*}$ & 11 & 13.2 \\
\hline
\end{tabular}

Except in the M3, almost all occlusal details of the cheek teeth are obliterated by wear. The P2 is subtriangular, longer than wide due the presence of a large parastylar lobe, which bears a low, bunoid, but very conspicuous parastyle. There is a single, strong convexity of the labial wall, corresponding to the paracone. A shallow notch separates the parastyle from the mesial aspect of the paracone. The metastyle is minute but distinct. A very broad platform of dentine lingual to the paracone indicates the presence of a well-developed protocone. Lingual to the parastyle, the mesial wall of the tooth is deeply notched, suggesting the absence (or extreme reduction) of the protoloph. A continuous, w-shaped labial cingulum connects the base of the parastyle with the metastyle. A less evident cingulum connects the mesial base of the protocone with the parastyle. The tooth bears a large lingual root associated to the protocone and two labial roots, the mesial one almost entirely related to the parastylar lobe. In contrast, in T. apthomasi, the P2 is simpler, two rooted, the parastylar lobe is less conspicuous, and it has no lingual cusp, only a small swelling of the paracone (see Paula-Couto, 1952, plate 41 and page 389). P3 and P4 (Figure 2.4) are subtriangular teeth, with conspicuous labial and anterolingual cingula, continuously convex lingual wall, mesiolabially pointed parastyle and prominent labial fold of the paracone separated by a deep parastylar sulcus, and distinct labial fold of the metacone adjacent to (but not connate with) the paracone, as in the Itaboraian species. Nevertheless, these premolars are proportionally larger than in T. apthomasi, especially the P3 (see Table 1). The very worn M1 and M2 (Figure 2.4) show the same trapezoidal outline as $T$. apthomasi, with a distinct lingual notch separating the protocone from the hypocone. However, they differ in having a slightly more prominent labial fold of the metacone, as in the premolars. The same condition is observed in the isolated molar from Cañadón Vaca MACN Pv CH1248 reported by Soria (1982) (Figure 2.5). The only discernible occlusal feature on the $\mathrm{M} 2$ is a narrow enamel fold invading distomesially the crown from the distal wall almost onethird of the molar length. The lingual edge of the fold clearly corresponds to the labial aspect of the hypocone and its associated distal cingulum. The labial edge is much more convex and would correspond to the lingual base of the metaconule. Consequently, at least in the $M 2$, the hypocone is deeply separated from the metaconule, as seen in MACN Pv CH1248 and in most Itaboraian specimens referred to $T$. apthomasi (see Appendix 1). The M3 (Figure 2.4) lacks most of the labial wall. It has a large protocone associated to a very conspicuous protoloph; the metaconule is small but distinct, sub-circular, and attached to the lingual base of the metacone. The more remarkable feature is the presence of a low but well distinct and bunoid hypocone attached to the distal base of the protocone, and separated from the posterior cingulum by a shallow notch. The same condition is observable in the isolated but less worn M3 MPEF PV 5481 (Figure 2.6). Similarly, the isolated upper molar AMNH 28450 from Cañadón Vaca, described by Simpson (1967, p. 234, figure 49) as a genus and species indeterminate, is almost surely a M3 and also shows a low hypocone attached to the distolingual base of the protocone, and isolated from the distal cingulum. This tooth nearly matches in size with the M3 of MPEF PV 5479 (see Table 1), and could belong to the same species. On the contrary, on the M3 of $T$. apthomasi, the hypocone is absent or vestigial (PaulaCouto, 1952), represented by a mere lingual swelling of the distal cingulum. 
Remarks. Dental features preserved in MPEF PV 5479 mostly match with those observed in the most complete Itaboraian specimens referred to Tetragonostylops apthomasi (e.g., DGM 355-M) in having trapezoidal M1 and M2 with distinct hypocone (unlike Trigonostylops), and conspicuous labial fold of the metacone (unlike Albertogaudrya, see Appendix 1). Nevertheless, it differs in being slightly larger, particularly the premolars (see Table 1 ), the P2 is more complex, P3-M2 have a more prominent labial fold of the metacone, and M3 has a distinct hypocone isolated from the distal cingulum. Although the identified differences would justify the recognition of a distinct species, these differential characters are not comparable in the holotype of $T$. apthomasi (an isolated and incomplete upper molar, DGM 154-M), and thus its cospecificity cannot be neither rejected nor corroborated. Consequently, we decided not to erect a new species, although very likely the specimens herein described from Cañadón Vaca belong to a species distinct from most of the specimens described by Paula-Couto $(1952,1963)$ as $T$. apthomasi. The isolated molar MACN Pv CH1248 reported by Soria (1982) is also referable to this species, being closer in size to the M1 than to M2 of MPEF PV 5479 (Table 1)

\section{cf. Scaglia cf. kraglievichorum Figures 3-6}

Material. MPEF PV 5478, a partial skull preserving left side of the rostrum, palate, orbital region, zygomatic arch, and both sides of the braincase and the basicranium. The maxillary preserves almost complete left P2 and P3, and partial and very cracked P4-M3.

Description and comparisons. The skull shows a significant distortion by oblique (latero-sagittal) post-mortem compression. All the preserved bones are cracked, and very few sutures could be identified. In lateral view, the rostrum is relatively long, low, and somewhat conical (Figure 3.1). Above the orbit, the forehead rises abruptly to an enormously long and elevated sagittal crest, although its height could be somewhat accentuated by the post-mortem distortion. Consequently, the entire dorsal profile shows a markedly sigmoid outline, strongly resembling that of the modern tapirs. Nevertheless, unlike tapirs and advanced astrapotheres, the nasals are not retracted. At least a short portion of both nasals is preserved at the roof of the rostrum; the preserved anterior tip is near the anterior border of the maxillary (Figure 3.2), and surely extended further when complete. The anterior portion of the nasals is very narrow, but then they broaden posteriorly to an undetermined extent; very likely they have an important contribution to the posterior portion of the roof of the rostrum. The lateral wall of the rostrum is represented essentially by the ascending process of the maxillary (the premaxillaries are missing) (Figure 3.1). The anterior portion is somewhat convex and represents the lateral wall of the alveolar sheath for the canine, which seems to have been much enlarged, as in other astrapotheres. Posteriorly, the maxillary becomes somewhat concave, likely due to distortion, since here the bone is collapsed or even missing, leaving exposed the labial roots of the cheek teeth. The infraorbital foramen is not clearly discernible, but it is likely represented by a single, deep depression above the roots of the P2, far anterior from the orbital rim (Figure 3.1). Only the anteroventral portion of the orbital rim is preserved, likely corresponding to the area of the lachrymal bone and its suture with the maxillary. Judging by the shape of this rim and the preserved parts of the surrounding broken bones, the orbit was rounded and proportionally small, as seen in other astrapotheres. The lacrimal foramen is single, conspicuous, and entirely intraorbital (concealed in lateral view). Although broken, the orbital rim immediately dorsal to the foramen is expanded laterally, suggesting the presence of a moderate lacrimal tubercle. The maxillary contribution to the intraorbital cavity is completely collapsed; however, the cheek teeth series ends much posterior relative to the presumed posterior border of the orbit, indicating that the maxillary formed a large suborbital floor. The jugal contribution to the ventral orbital rim is missing, thus the presence of a frontal process is uncertain. The zygomatic arch, at least its squamosal portion, is high and robust, convex laterally, and roughly concave medially (Figure 3.1-3). In its current state, the arch is set very ventral, with the posterior root more ventral than the anterior root. However, the arch seems to have been rotated due to the post-mortem distortion, since the posterior root is separated from the braincase by a conspicuous fissure, and it is inclined ventrally, much more than its counterpart on the right side. Very likely, the zygomatic arch was originally more elevated, with the posterior root at the level of (or more dorsal than) the anterior one, as shown in the schematic reconstruction (Figure 4). The dorsal margin of the arch extends posteriorly as a conspicuous crest above the auditory meatus and continues with the dorsal relief of the lambdoid crest (preserved on the right side of the skull), as in Trigono- 

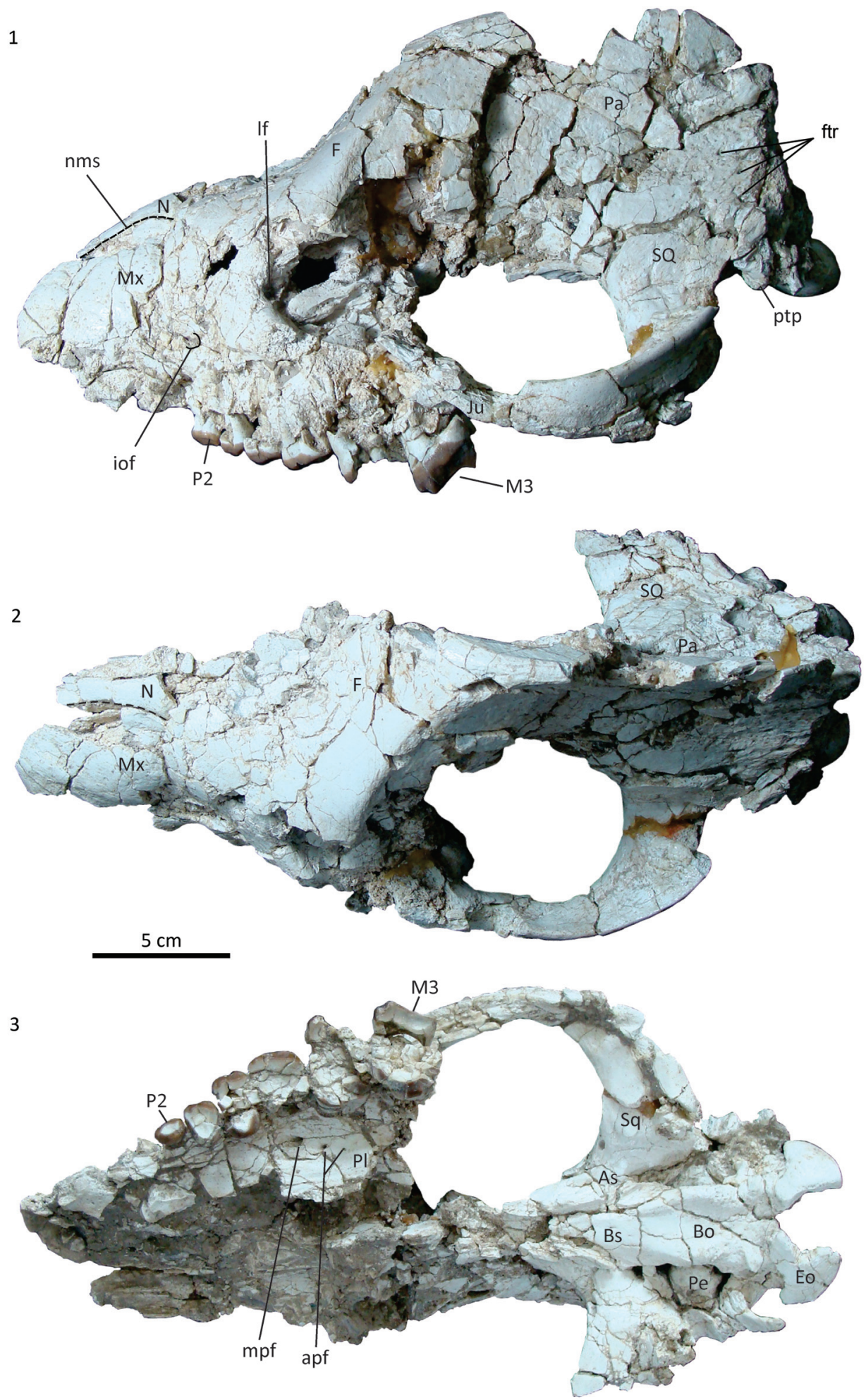

FIGURE 3. cf. Scaglia cf. kraglievichorum, MPEF PV 5478, partial skull. 1, lateral view; 2, dorsal view; 3, ventral view. Abbreviations: apf=accessory palatine foramina, $\mathrm{As}=$ alisphenoid, $\mathrm{Bo}=$ basioccipital, $\mathrm{Bs}=$ basisphenoid, Eo=exoccipital, $F=$ frontal, ftr=foramina for temporal rami, iof=infraorbital foramen, Ju=jugal, If=lacrimal foramen, $M x=$ maxillary, $\mathrm{mpf}=$ major palatine foramen, $\mathrm{N}=$ nasal, $\mathrm{nms}=$ naso-maxillary suture, $\mathrm{Pa}=$ parietal, $\mathrm{Pe}=$ petrosal, $\mathrm{ptp}=$ posttympanic process of squamosal, $\mathrm{Sq}=$ squamosal. 


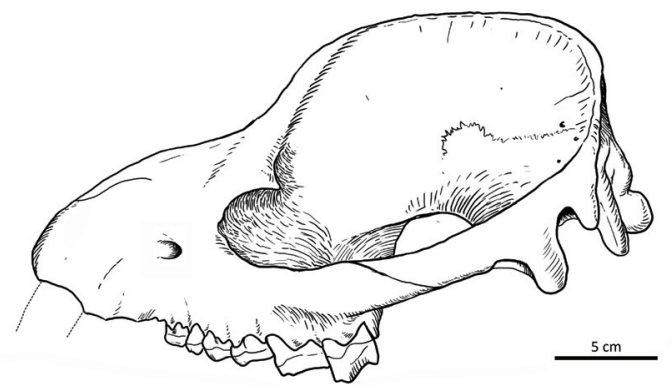

FIGURE 4. cf. Scaglia cf. kraglievichorum, MPEF PV 5478. Schematic partial reconstruction of the skull, in lateral view. stylops and Astraponotus, but unlike in Astrapotherium (see Appendix 1).

In dorsal view (Figure 3.2), the skull roof is narrow in front of the orbit (but probably emphasized due to deformation), and it broadens above the orbits. The maximum widening coincides with a marked lateral expansion of the frontals, which would represent the base of the postorbital process. Behind the process, the frontals form an extensive triangular surface that ascends up to the origin of the sagittal crest. The lateral margins are defined by the little prominent temporal crests connecting the base of the postorbital process with the
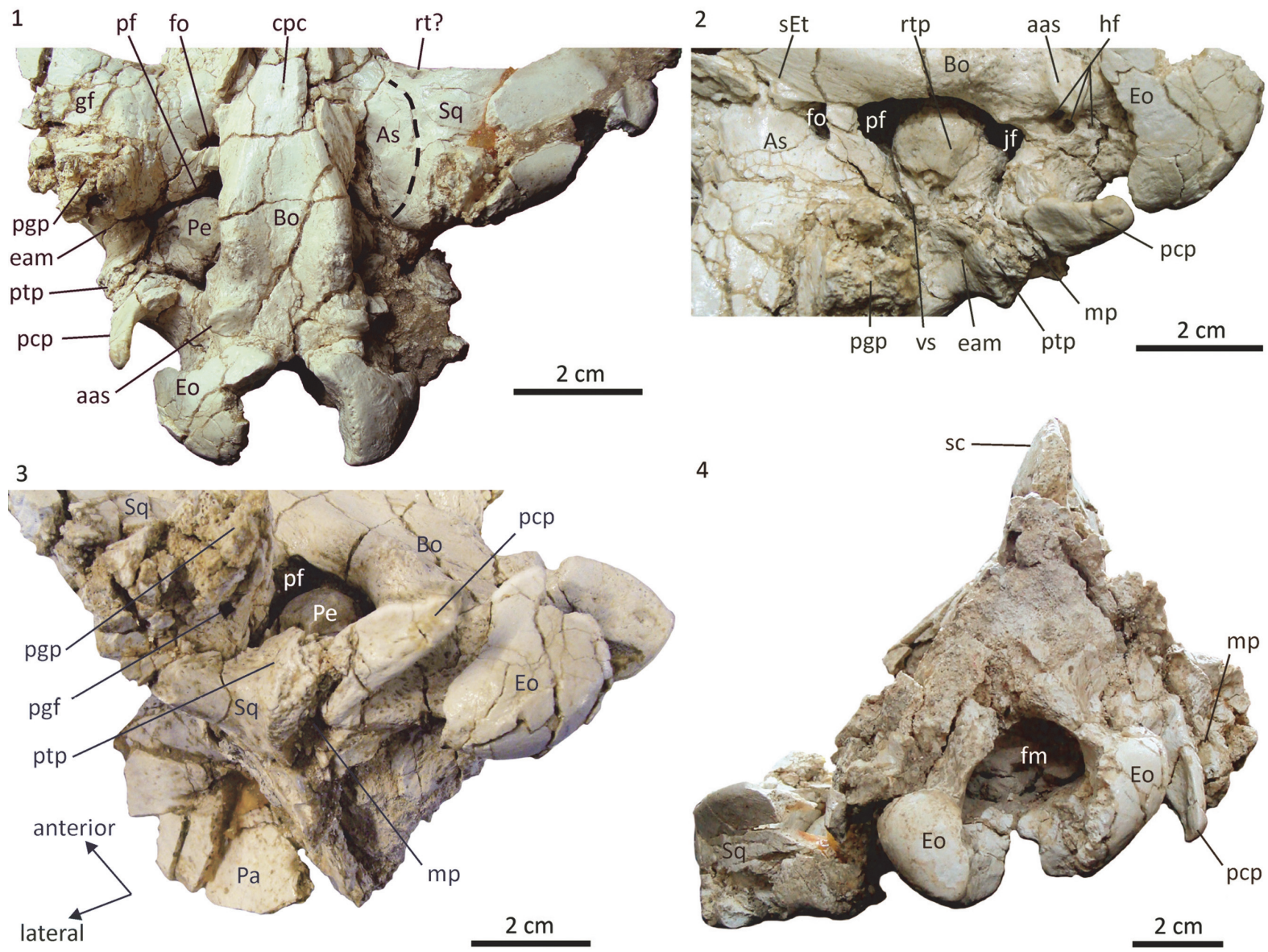

FIGURE 5. cf. Scaglia cf. kraglievichorum, MPEF PV 5478. 1, skull base in ventral view (anterior to top); 2, detail of the auditory region in ventrolateral view (anterior to left); 3, detail of the auditory region in posteroventral view. 4, occipital view. Abbreviations: aas=accessory articular surface of the basioccipital, As=alisphenoid, Bo=basioccipital, $\mathrm{cpc}=$ foramen for the craniopharyngeal canal, eam=external acoustic meatus, Eo=exoccipital, fm=foramen magnum, $\mathrm{fo}=$ foramen ovale, $\mathrm{gf}=\mathrm{glenoid}$ fossa, $\mathrm{hf}=$ hypoglossal foramina, $\mathrm{jf}=\mathrm{jugular}$ foramen, $\mathrm{mp}=$ mastoid process, Pa=parietal, $\mathrm{pcp}=$ paracondilar process, $\mathrm{Pe}=$ petrosal, $\mathrm{pf}=$ =piriform fenestra, pgf=postglenoid foramen, pgp=postglenoid process, $\mathrm{ptp}=$ posttympanic process of squamosal, $\mathrm{rtp}=$ rostral tympanic process, $r \mathrm{rt}=\mathbf{=}$ possible exit for an anterior derivation of a temporal ramus, $\mathrm{sEt}=$ sulcus for the Eustachian tube, sc=sagittal crest, $\mathrm{Sq}=$ squamosal, vt=ventral stem (vestige of the ectotympanic?). 
origin of the sagittal crest. Behind this point, the skull roof is represented by the enormously high and long sagittal crest, composed of the nearly vertical parietals. The braincase is very narrow and high, although this condition could be exaggerated by the distortion. Near the presumed contact with the squamosals, the parietals bear multiple vascular foramina (exits for temporal rami) (Figure 3.1). The supraoccipitals are missing, but the occiput seems to have been high and nearly vertical; the connection of the sagittal crest with the lambdoid crests, as seen in Trigonostylops, is uncertain.

Because of the distortion, the left side of the palate (the right one is missing) was displaced laterally far from the sagittal plane, which is inferred by an imaginary anterior projection of the midline of the basioccipital and the basisphenoid bones, and thus the palate looks wider than it would have been originally (Figure 3.3). The palate is essentially plane, somewhat wider at the level of M2 than at $\mathrm{P} 3$. There is a conspicuous palatine foramen at the level of the M1, set at the palate-maxillary suture (major palatine foramen), and two accessory foramina on the palatine at the level of the M2. A small portion of the anterior border of the choanae is preserved at the level of the posterior margin of M2, nearly as in Astraponotus, more anterior than in Scaglia and Trigonostylops. The pterygoids only preserved the bases of the pterygoid crests flanking the basisphenoid and their extensions on the alisphenoid. The crests diverge posteriorly and reach a point near the anterior margin of the oval foramen (Figures 3.3, 5.1). The grooves for passage of the Eustachian tubes are conspicuous (Figure 5.2). There are three tiny foramina on the ventral aspect of the basisphenoid; the anterior one is the largest and located on the midline, the posterior ones are paired and located close to the presumed position of the suture with the basioccipital (Figure 5.1). They could be nutrient foramina, although the anterior foramen could correspond to the exit of the craniopharyngeal canal (also present in some notoungulates, see MacPhee, 2014). The alisphenoids form most of the skull floor in front of the auditory cavities. The suture with the squamosal runs from the lateral base of the postglenoid process and traces an ample curve convex laterally. The anterior section of the suture shifts medially before reaching the anterior edge of the posterior root of the zygoma, thus this edge is entirely formed by the squamosal (Figure 5.1). The extension of the alisphenoids into the orbitotemporal region cannot be determined clearly. The anterior portion of the alisphenoids is essentially flat and featureless, with no evidence for presence of alisphenoid canal. The main feature of the alisphenoid is a remarkable depression on its posterior portion that leads to an opening to the cranial cavity (Figures 3.3, 5.1-2). The opening is somewhat wider than longer; it is set near the presumed contact with the basisphenoid, and separated from the large fissure between the alisphenoid and the petrosal by a transverse bony bridge (preserved only on the right side of the skull). The aperture is very likely for the passage of the mandibular ramus of the trigeminal nerve (i.e., the oval foramen). Contrarily, there is no separate exit for the mandibular ramus in Astraponotus and all known postEocene astrapotheres (Parastrapotherium, Astrapotherium, Granastrapotherium, etc.; see Appendix 1). Billet (2010), followed by Kramarz et al. (2017), interpreted that the only known basicranium of Trigonostylops (AMNH 28700, see Simpson, 1933) lacks a separate aperture for the mandibular ramus. Nevertheless, in the AMNH 28700 the preserved tympanic bones conceal the posterior portion of the exits of the mandibular rami; the only unambiguous feature is the presence of a longitudinal thin septum of the alisphenoid (posterior extension of the pterygoid crest) separating the oval foramen or incisure (laterally) from the piriform fenestra (medially), but the presence of a complete bony ridge between these apertures is uncertain. In Scaglia, the recent repreparation of the preserved parts of the basicranium revealed the presence of a distinct foramen on the alisphenoid [not described by Simpson (1957)] likely corresponding to the foramen ovale. In MPEF PV 5478, the posterior root of the zygoma is massive, very wide (lateromesially), and mostly formed by the squamosal (Figure 5.1). The glenoid fossa is nearly flat anteriorly and concave posteriorly, with no clear lateral and medial limits. The preserved bases of postglenoid processes indicate that the processes were high, massive, and much wider than longer (Figure 5.1). Both squamosals bear a conspicuous foramen located on the anterior wall of the zygomatic root, near the contact with the alisphenoid (Figures 3.3, 5.1). We have not found this feature in any astrapothere, panperissodactyl, or other placentals we compare with. The foramina face anteroventrally to the orbitotemporal fossa, but they are set too lateral to be for passage of a derivation of the ramus infraorbitalis (which typically perforates the alisphenoid). We interpret that they more likely served for passage of an unusually anterior derivation of some of the temporal rami of the stapedial system or for a 


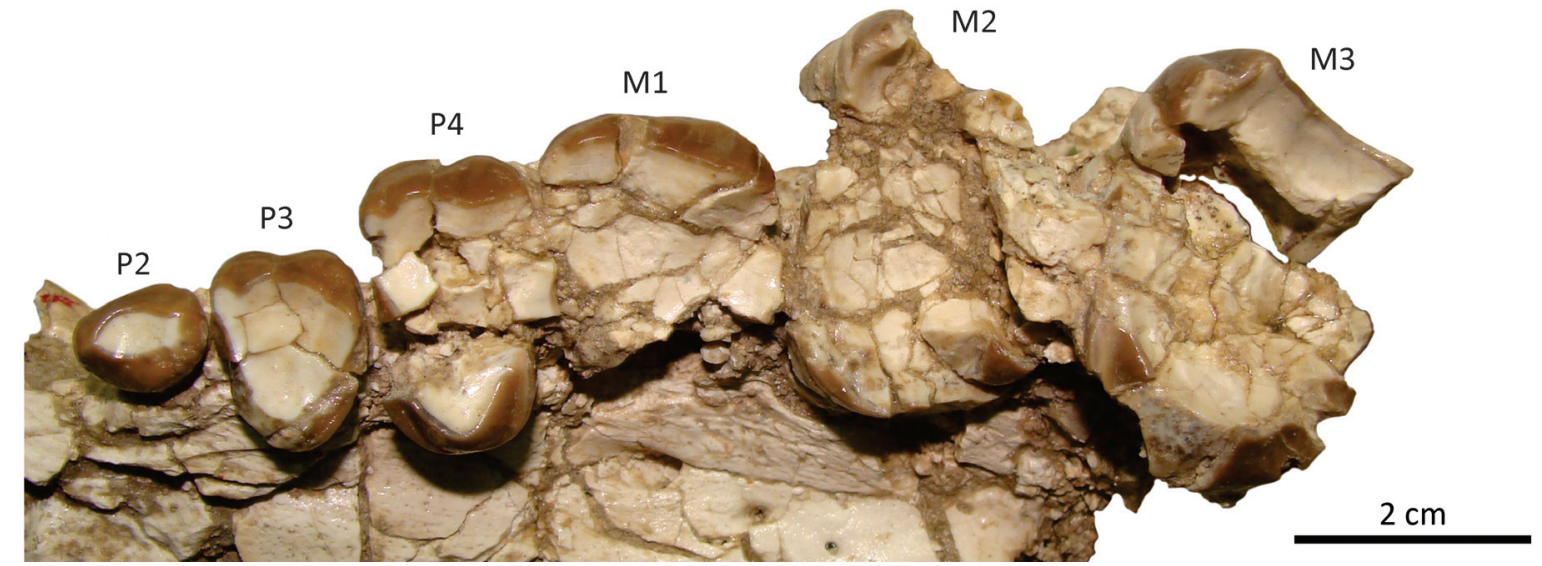

FIGURE 6. cf. Scaglia cf. kraglievichorum, MPEF PV 5478. Detail of the left P2-M3 series in occlusal view.

venous system related to the postglenoid vein (see Muizon et al., 2015). Behind the postglenoid process, the squamosal forms a wide platform above the external auditory meatus, which is represented by a very deep notch between the postglenoid and the posttympanic processes (Figure 5.1-3). A minute foramen on the posterior base of the postglenoid process likely corresponds to the postglenoid foramen. Contrarily, Astraponotus has no distinct postglenoid foramen, whereas Trigonostylops and Astrapotherium have an enormous foramen in postglenoid position (although its relation with the postglenoid vein is unclear). The posttympanic process of the squamosal is transversely wide and abuts the mastoid process of the petrosal (Figure 5.1-3). It is significantly shorter (vertically) than the postglenoid process (Figure 5.1-3), longer than in Trigonostylops, but much shorter than in Astraponotus and Astrapotherium. A prominent ridge of the squamosal connects the medial margin of the posttympanic process with the base of the postglenoid process, and forms the dorsal edge of the external acoustic meatus (Figure 5.1-2).

As in all astrapotheres, the petrosal is set very deep in the tympanic cavity, more dorsal than the level of the basioccipital (Figure 5.1-3). There is a large, continuous gap separating the petrosal from the entire posterior margin of the alisphenoid, the basisphenoid, and the basioccipital. The gap is larger at the anteromedial corner of the cavity (immediately posterior to the foramen ovale, encompassing the piriform fenestra) and at the posteromedial corner (coinciding with the position of the jugular foramen). On the anteromedial corner, there is no clear notch or indication for the passage of the Eustachian tube or for the internal carotid artery (if existed). The promontorium is moderately globose, nearly as wide as long, and bears a crest-like rostral tympanic process crossing the ventrolateral aspect of the promontorium (Figure 5.2), as in Astrapotherium (see Kramarz et al., 2017). The right petrosal (better preserved than the left one) shows no trace of either vascular sulci or anterior and medial flanges. Most of the lateral surface of the promontorium is not preserved, including the entire peripheral margins of the cochlear fossula and most of the vestibular fenestra. As in Astrapotherium, the post-promontorial tympanic sinus is ample and shallow, and it is not isolated from the jugular notch; the stapedius fossa is very deep and continuous with the facial sulcus, which in turn is continuous with the preserved roof of the cavum supracochleare (the floor is not preserved). There is a small stem projecting ventrally from the lateral wall of the cavum supracochleare (Figure 5.2). This element could be homologous to the ventral projection of the anterior end of the tegmen tympani, described as the ventrolateral tuberosity in some cetartiodactyls (see Luo and Gingerich, 1999; O'leary, 2010). The tip of this stem is separated from the base by a thin layer of matrix and likely correspond to a minute portion of the tympanic bone. A small, somewhat concave surface between this stemming and the crested base of the tympanohyal would represent the petrosal contribution to the epitympanic recess. The mastoid process is a narrow wedge appressed between posttympanic process of the squamosal and the paracondylar process of the exoccipital, moderately exposed in ventral (Figure 5.2-3) and lateral views, and a minor exposure in occipital view (Figure 5.4), as in Trigonostylops. Contrarily, in Astraponotus and Astrapotherium the mastoid process is completely concealed by the very strong 
posttympanic process of the squamosal. The tympanic bone is missing, except a minute piece articulated with the presumed ventrolateral tuberosity of the petrosal mentioned above. The latter and the sharp anterior margin of the post-tympanic process of the squamosal are the only preserved structures potentially for the attachment of the very likely ringlike ectotympanic.

The suture between the basisphenoid and the basioccipital is not discernible, and the ventral surface of both bones are continuous and in the same plane (Figures $3.3,5.1$ ). The basioccipital is very wide, with a slight concavity in the midline limited by elevated lateral borders, which end posteriorly in paired marked tubercles (basilar tubercles?) located at the level of the posterior border of the promontorium, much posterior than the presumed position of the basisphenoid - basioccipital suture (Figure 5.1). The tubercles and the median fossa between them could have served for insertion of the rectus capitis ventralis muscles, which bend the head down toward the chest. The tapirs have delicate and sharp crest in a similar position. Behind the tubercles, the ventrolateral aspect of the basioccipital bears a pair of elevated and transverse articular facets, separated from the tubercles by a short depression (Figure 5.1-2). The occipital condyles are ovoid, protruding and well separated; they have a moderate anterior extension of the articular surface (flexion stops sensu Janis and Scott, 1987; O'Leary and Gatesy, 2008), as seen in Trigonostylops and Astrapotherium, but the extension is more convex, following the curvature of the ventral surface of the condyle. A deep notch separates the anterior margin of these articular surfaces from the articular facets of the basioccipital described above. Flexion stops are usual in many artiodactyls and perissodactyls ( $\mathrm{O}^{\prime}$ Leary and Gatesy, 2008), but the accessory surfaces are flat or even concave. In MPEF PV 5478, the role of the flexion stops would have been played by the accessory articular surfaces of the basioccipital instead of by the anterior extensions of the condylar surfaces. The exoccipital forms a lateral shelf posterior to the tympanic cavity and anterior to the condyle, somewhat more dorsal than the level of the basioccipital. The anterior margin of this shelf has a deep, subcircular notch, which forms the entire posterior border of the jugular foramen (Figure 5.1-2). The paracondylar process (paraoccipital process of Muizon et al., 2015) protrudes from the anterolateral margin of the shelf. The process is very high, blade like, convex anteriorly and concave posteriorly, wider than long in the base but becoming narrower to the tip. The process projects posteroventrally and slightly medially, but very likely it is the result of the distortion and the original configuration was more vertical. Two small hypoglossal foramina open within a sub-rounded depression at the medial part of the occipital shelf, lateral to the accessory facet of the basioccipital, and well separated from the jugular foramen (Figure 5.2). The foramina are separated by a very thin and oblique (anterolateral-posteromedial) septum; the anteriomedial foramen is larger and more ovoid. A third, very minute foramen is set in a separate and smaller depression, immediately posterior to the former depression. On the contrary, in all the remaining astrapotheres, the hypoglossal foramen is single and opens in a common depression with the jugular foramen, a condition interpreted as a synapomorphy of Astrapotheria in previous phylogenetic analyses (Billet, 2010; Billet et al., 2015; Muizon et al., 2015; Kramarz et al., 2017).

The canines are not preserved, except several fragments of dentine within the very damaged left alveolar sheath; judging by the curvature of the anterior margin of the maxillary (Figure 3.1), the canine would have been an enlarged tusk, as much as in Astraponotus. There is a long diastema in front of the P2 (Figure 3.3), although the existence of an alveolus for the P1 immediately behind the alveolus for the canine cannot be discarded. The P2 is the best preserved tooth. The crown is low, longer than wide, with a main central, somewhat elongated cusp with keeled anterior aspect and a short posterior talon (Figure 6). There is a feeble labial cingulum and a narrow basal swelling on the lingual side that forms an irregular and minute shelf. The exposed labial side of the root shows a conspicuous vertical cleft, absent on the lingual side; since this is a very simple tooth, we consider that it more likely has a single root with a labial cleft instead of three roots. In Trigonostylops, the P2 has an anterior and a posterior root, whereas in Astraponotus the P2 is three rooted (Kramarz et al., 2010). The P3 is a triangular tooth, wider than long (Figure 6). The preserved enamel outline on the labial side is a main convexity, suggesting a single main labial cusp, with an anterolabial outgrowth corresponding to the parastyle. Distally, the enamel border does not follow the contour of the base of the crown, but it bends lingually, leaving a small basal fovea on the distolabial corner. The lingual half of the mesial margin is missing, but at least a short labial section of a weak anterior cingulum is preserved departing from the base of the parastyle. The very worn posterior cingulum is rep- 
resented by a narrow shelf crossing the lingual two-thirds of the posterior margin of the crown. The labial base lacks cingulum. The tooth has a main lingual root and two small labial roots. The subsequent teeth are badly preserved, very cracked, and incomplete (Figure 6). The P4 is also subtriangular and three-rooted. The length of the labial wall is larger than in P3, but the actual width of the tooth is undeterminable since it preserves the lingual and the labial portions separated by several cracked and scattered fragments of dentine and enamel of the center of the crown. The anterior half of the labial wall preserves a conspicuous fold of the paracone and of the parastyle separated by a faint parastylar groove. The distal half of the labial wall is essentially flat, with no trace of the labial fold of the metacone, although the cusp could be entirely subsumed within the ectoloph. The lingual portion bears a single cusp flanked by broad anterior and posterior cingula, which are not connected on the lingual base. The labial cingulum is absent. The M1 only preserved the base of the labial half of the crown (Figure 6). The crown is much longer mesiodistally than the P4. The short preserved portions of the mesial and distal margins of the crown are parallel (i.e., do not converge lingually), suggesting that the tooth was quadrangular or trapezoidal instead of triangular. The same contour is deduced for the M2 and M3 (Figure 6). M2 is larger than M1 and subequal to M3. The labial wall of the M3 bears distinct folds of the parastyle and the paracone, and flat labial wall of the metacone (no labial fold). A small preserved portion of the mesiolingual margin reveals the presence of a broad anterior cingulum. In all the cheek teeth, the enamel shows vertically decussating HunterSchreger enamel bands, as in all astrapotheres.

Remarks. Most of Eocene astrapothere taxa are defined on dental characters. In MPEF PV 5478, most of the cheek teeth are very poorly preserved, and thus the comparisons with previously defined taxa are very difficult and mainly limited to the size and gross features of the dentition. Upper molars of MPEF PV 5478 have quadrangular or trapezoidal outline, suggesting the presence of a more or less developed hypocone, unlike in Trigonostylops. Moreover, MPEF PV 5478 is much larger (the skull length is at least $50 \%$ larger), has much higher sagittal crest, higher posttympanic process of the squamosal, more medially placed foramen ovale, smaller postglenoid foramen, accessory articular surfaces on the basioccipital, and multiple hypoglossal foramina separated from the jugular foramen. MPEF PV 5478 differs from Tetragonostylops by being also much larger, and the molars lack labial fold of the metacone (well marked in the Itaboraí genus). Compared with the skull MPEF PV 5479 described above as Tetragonostylops aff. $T$. apthomasi, it differs by having very raised frontals and enormously elevated sagittal crest, among other minor details. The cheek teeth of MPEF PV 5478 differ from those of Albertogaudrya (whose skull is unknown) by being significantly smaller. Comparing the length of the cheek teeth, the P4 of Albertogaudrya is nearly $37 \%$ larger, and the M1 and $\mathrm{M} 2$ are approximately $28 \%$ larger. In addition, the P3 and P4 of Albertogaudrya have a rudimentary but distinct cingular hypocone, conspicuous labial fold of the metacone, and the cheek teeth have prominent labial cingulum. Astraponotus and younger astrapotheres are gigantic compared with MPEF PV 5478 and have a definitively different skull design (see Kramarz et al., 2010). The only known astrapothere comparable with MPEF PV 5478 is Scaglia kraglievichorum, known by a juvenile skull with deciduous dentition and erupting M1 (MMP M-207), also derived from Cañadón Vaca (Simpson, 1957, 1967). The M1 is the only comparable tooth, unworn in $S$. kraglievichorum and heavily worn and incomplete in MPEF PV 5478. Nevertheless, the length of the labial wall in $S$. kraglievichorum (measured in the base) is almost identical to that in MPEF PV 5478 (see Table 2). In addition, in both skulls the nasals are not retracted; they are narrow anteriorly but greatly expanded posteriorly, although the expansion is more posterior in the holotype of $S$. kraglievichorum. Both skulls have a separate aperture for the mandibular ramus of the trigeminal nerve (but see comments above on Trigonostylops). Certainly, many other features of the juvenile skull of $S$. kraglievichorum are noticeably different: the orbits are proportionally larger, and the supraorbital broadening of the frontals is much less marked, the skull roof is flat to moderately domed in the frontal region, and definitively vaulted in the temporal region, with a weak and comparatively short sagittal crest. As noted by Simpson $(1957,1967)$, this juvenile cranial design would change during the ontogeny to a less vaulted skull. Comparing with an extant analog, in juvenile specimens of Tapirus terrestris (see Appendix 1), the braincase is very globolous, the temporal and sagittal crests are almost indistinct, the orbit are proportionally larger, and the rostrum and the temporal region are shorter than in adults, which are essentially the same differences between the type of $S$. kraglievichorum and the MPEF PV 5478. The deciduous premolars pre- 
TABLE 2. Dental measurements (in mm) of cf. Scaglia cf. kraglievichorum from Cañadón Vaca compared with the holotype of Scaglia kraglievichorum (MMP M-207) and with Albertogaudrya unica. Abbreviations: mdl, maximum distolabial length; trw, transverse width. * denotes approximate measurement.

\begin{tabular}{|c|c|c|c|c|c|c|c|c|c|c|c|c|c|}
\hline \multirow[b]{2}{*}{ Taxon } & \multirow[b]{2}{*}{ Specimen } & \multicolumn{2}{|c|}{ P2 } & \multicolumn{2}{|c|}{ P3 } & \multicolumn{2}{|c|}{ P4 } & \multicolumn{2}{|c|}{ M1 } & \multicolumn{2}{|c|}{ M2 } & \multicolumn{2}{|c|}{ M3 } \\
\hline & & mdl & trw & mdl & trw & mdl & trw & mdl & trw & mdl & trw & mdl & trw \\
\hline $\begin{array}{l}\text { cf. Scaglia cf. } \\
\text { kragilevichorum }\end{array}$ & MPEF PV 5478 & 11.6 & 8.1 & 12.2 & 16.3 & 13.4 & & 19.3 & & & 33 & 23.7 & 34.7 \\
\hline Scaglia kraglievichorum & MMP 207 (holotype) & & & & & & & 19.4 & 21.4 & & & & \\
\hline \multirow[t]{3}{*}{ Albertogaudrya unica } & MACN A 12000 & & & 17.8 & 26.6 & & & & & 28.8 & 37.1 & & \\
\hline & MACN A 12004 & & & & & & & & & 30.6 & 38.1 & & \\
\hline & AMNH 28639 & & & & & 18.5 & 32 & 25.1 & 36.2 & & & & \\
\hline
\end{tabular}

served in the holotype of $S$. kraglievichorum are molariform teeth, whereas the permanent premolars MPEF PV 5478 have much simpler crowns. However, the replacement of deciduous molariform premolars by non-molariform premolars is the rule among astrapotheres, as seen in Astraponotus (see Kramarz et al., 2010). In sum, we concluded that MPEF PV 5478 is more likely an adult of $S$. kraglievichorum than a representative of a new taxon. The evidence supporting this idea is certainly weak, but at present there is no available evidence against this assignment.

Interestingly, MPEF PV 5478 lacks two of the cranial synapomorphies identified for Astrapotheria by Billet (2010). In all known astrapotheres, the hypoglossal foramen is single and opens in a common depression with the jugular foramen (e.g., Trigonostylops), or both are very close (e.g., Astrapotherium, Astraponotus), whereas the skull MPEF PV 5478 has multiple hypoglossal foramina well separated from the jugular foramen. Likewise, the skull MPEF PV 5478 lacks the large foramen in postglenoid position piercing the base of the postglenoid process, present in Trigonostylops and in all Oligo-Miocene astrapotheres (although not in Astraponotus). Furthermore, MPEF PV 5478 and the type of $S$. kraglievichorum have a separate foramen ovale, while this foramen merged with the piriform fenestra was found as a shared apomorphy between astrapotheres, pyrotheres, and notoungulates (Billet, 2010). Probably, these conditions in MPEF PV 5478 are autapomorphic reversions, but their occurrence in this Eocene astrapothere reveal that the phylogenetic implications of these characters needs to be re-assessed.

\section{Astrapotheriidae genus and species A Figure 7}

Material. MPEF PV 5477, and anterior portion of right dentary with i3, p2-p4 and partial alveoli for i1, i2, $\mathrm{c} 1, \mathrm{p} 1$, and $\mathrm{m} 1$.
Description and comparisons. The mandible MPEF PV 5477 has suffered a significant distortion, essentially by lateral compression. In its current state, the mandibular fragment is unusually high and narrow, especially the symphysiary region. The chin is mostly flat and remarkably upraised, in an angle of nearly $45^{\circ}$ with respect to the alveolar line (Figure 7.1-3). Beneath the opening of the alveolus for the canine, the chin bulges out forming a prominent, sub-cylindrical sheath for the base of the canine. Behind this sheath, the lateral aspect of the dentary bears an evident subvertical depression, likely to lodge the upper canine, as seen in Tetragonostylops. However, this area shows a high density of cracks and some bone fragments are dislocated, and very likely the distortion has accentuated the depth of the postcanine depression.

The post-canine diastema is a sharp and long crest; the posterior portion is aligned with the cheek tooth row but the anterior portion curves outwards behind the alveolus for the canine, which is set more lateral than the cheek tooth row (Figure 7.2). The dorsal surface of the symphysis is a long and deep gutter ending at a point anterior to the p2. The height between the dorsal and ventral walls of the symphysis, which essentially corresponds to the internal section of the alveolus for the canine, is enormous (Figure 7.3). Posterior to the end of the symphysis, the preserved portion of the ventral border of the jaw rises posteriorly, and thus the ramus is noticeably lower above the $\mathrm{p} 4$ than above the p2 (Figure 7.1-3). At least four small mental foramina open rather high on the lateral aspect of the mandible; the anteriormost is set at the level of the posterior third of the post-canine diastema, the posteriormost is below the roots of the p3 (Figure 7.1). Presence of additional foramina could be obscured by the abundant cracks below the diastema. The symphysis of Albertogaudrya described by Simpson (1967, p. 230) is 

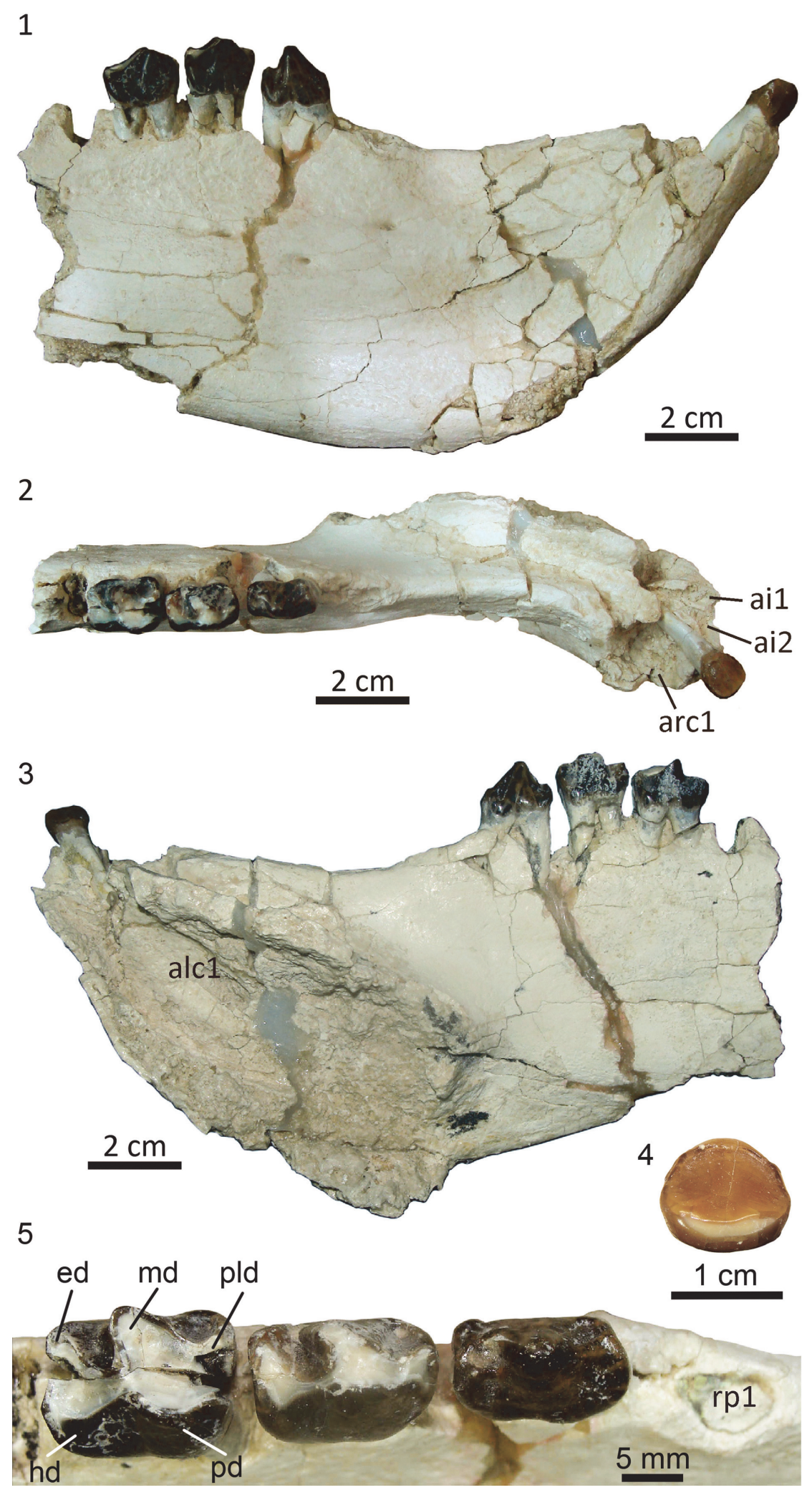

FIGURE 7. Astrapotheriidae genus and species A, MPEF PV 5477, anterior portion of right dentary with i3, p2-p4 and partial alveoli for i1, i2, c1, p1, and m1. 1, lateral view; 2, dorsal view; 3, medial view; 4 , i3 in occlusal view; 5 , detail of p2-p4 in occlusal view. Abbreviations: ai1= alveolus for right i1, ai2=alveolus for right i2, arc1=alveolus for right $\mathrm{c} 1$, alc1=alveolus for left $\mathrm{c} 1$, ed=entoconid, hd=hypoconid, $\mathrm{md}=$ =metaconid, $\mathrm{pd}=$ protoconid, pld=paralophid, $\mathrm{rp} 1=$ root of $\mathrm{p} 1$. 
definitively much lower, more procumbent, and ends beneath the p3. Moreover, in the syntype of Albertogaudrya unica (MACN A 12001), the jaw above p4 is higher, or as high as, above p2. Other early astrapotheres are much smaller and with a proportionally slenderer jaw than in MPEF PV 5477.

The alveoli for $\mathrm{i} 1$-i2 are incomplete and somewhat deformed, although they seem to have been roughly similar to that of i3. The crown of the i 3 is low, moderately spatulate (broader apically than in the base), convex labially, with a very faint depression on the center of the lingual wall, barely insinuating a symmetrical bilobation (Figure 7.4). A concave cingulid connects the mesial and distal edges along the lingual base of the crown. There is no labial cingulid, but a succession of minute denticles of enamel connecting the mesial and distal walls, mirroring the trajectory of the lingual cingulid. There is a single wear facet on the apex of the crown. The root is very long and mesiodistally compressed. The morphology of the incisors of Tetragonostylops and Albertogaudrya is very imperfectly known. In Trigonostylops, the incisors show no bilobation (Simpson, 1967), whereas in Astraponotus the bilobation is more pronounced. The alveolus for the canine is very large, although the exact contour of the external border is not preserved, the tooth would have had a roughly ovoid cross section. The alveolus penetrates very deep within the jaw, passing below the root of the i3, up to a very low point below and medial to the root of the $\mathrm{p} 1$ (Figure 7.3). Judging by the orientation of the alveolus, and even considering the distortion, the crown of the canine was more extroverted and less procumbent than in the edentulous symphysis AMNH 28641 described by Simpson as belonging to Albertogaudrya. There is a very long diastema (longer than the p2-p4 length) separating the canine from the alveolus for $\mathrm{p} 1$ (Figure 7.2). The alveolus for the $p 1$ is moderately large, longer than wide. Although single, the root would have had a small vertical partition on the lingual side. The alve- olus for the $\mathrm{p} 2$ is separated from the $\mathrm{p} 1$ by a minute diastema, much shorter than the length of the alveolus for the p1. In Tetragonostylops and Trigonostylops, the $\mathrm{p} 1$ (when present) is separated from the p2 by a longer or much longer diastema. According to Simpson (1967), Albertogaudrya lacks $\mathrm{p} 1$. The crown of the $\mathrm{p} 2$ has no evident wear facets (Figure 7.5). The crown is almost as large as the p3 (see Table 3), longer than wide, with a large central, slightly trenchant cuspid. A very feeble cristid descends from the anterior aspect of the central cuspid up to the center of an elevated and broad mesial cingulid. The posterior heel is very small and much lower than the central cuspid. It bears a shallow basin limited on the lingual side by a faint enamel ridge descending from the distolingual aspect of the central cuspid and, on the labial side, by an even less prominent ridge stemming from the distal base of the main cuspid. The latter extends distally up to a minute cuspid on the distal margin of the crown, which completes the posterior edge of the talonid basin. The anterior cingulid is very conspicuous along the mesial base and extends a short distance on the lingual side. The posterior cingulid is reduced to a very faint enamel swelling on the distolingual base of the crown. The labial and lingual cingulids are absent. The tooth has two (anterior and posterior), robust, sub-cylindrical, and divergent roots (Figure 7.1). In Albertogaudrya, the p2 lacks a mesial cingulid (as in Tetragonostylops), the central cuspid is more conical, the talonid and its distal cuspid are more conspicuous, and the talonid basin is deeper and opens on the lingual side. In Trigonostylops, the talonid is also more conspicuous and bears two minute cuspids in the hypoconid and entoconid positions. Additionally, in all compared taxa the p2 is consistently smaller than the p3. In MPEF PV 5477 , the p3 is morphologically transitional between p2 and p4. The p4 is almost entirely molariform and bicrescentic (Figure 7.5), with distinct protoconid and metaconid and incipient paralophid in the trigonid, and well-developed tal-

TABLE 3. Dental measurements (in $\mathrm{mm}$ ) of Astrapotheriidae genus and species A from Cañadón Vaca compared with Albertogaudrya unica. Abbreviations: mdl, maximum distolabial length; trw, transverse width.

\begin{tabular}{|c|c|c|c|c|c|c|c|c|c|}
\hline \multirow[b]{2}{*}{ Taxon } & \multirow[b]{2}{*}{ Specimen } & \multicolumn{2}{|c|}{ i3 } & \multicolumn{2}{|c|}{ p2 } & \multicolumn{2}{|c|}{ p3 } & \multicolumn{2}{|c|}{ p4 } \\
\hline & & mdl & trw & mdl & trw & mdl & trw & mdl & trw \\
\hline $\begin{array}{l}\text { Astrapotheriidae genus } \\
\text { and species } A\end{array}$ & MPEF PV 5477 & 10 & 8.7 & 15.1 & 9 & 15.2 & 10.3 & 15.5 & 12.2 \\
\hline \multirow[t]{2}{*}{ Albertogaudrya unica } & MACN A 12001 & & & 16.3 & 12.5 & 20 & 15.3 & 20.5 & 16 \\
\hline & MACN A 12002 & & & & & 17.3 & 13.3 & 20.1 & 15.3 \\
\hline
\end{tabular}




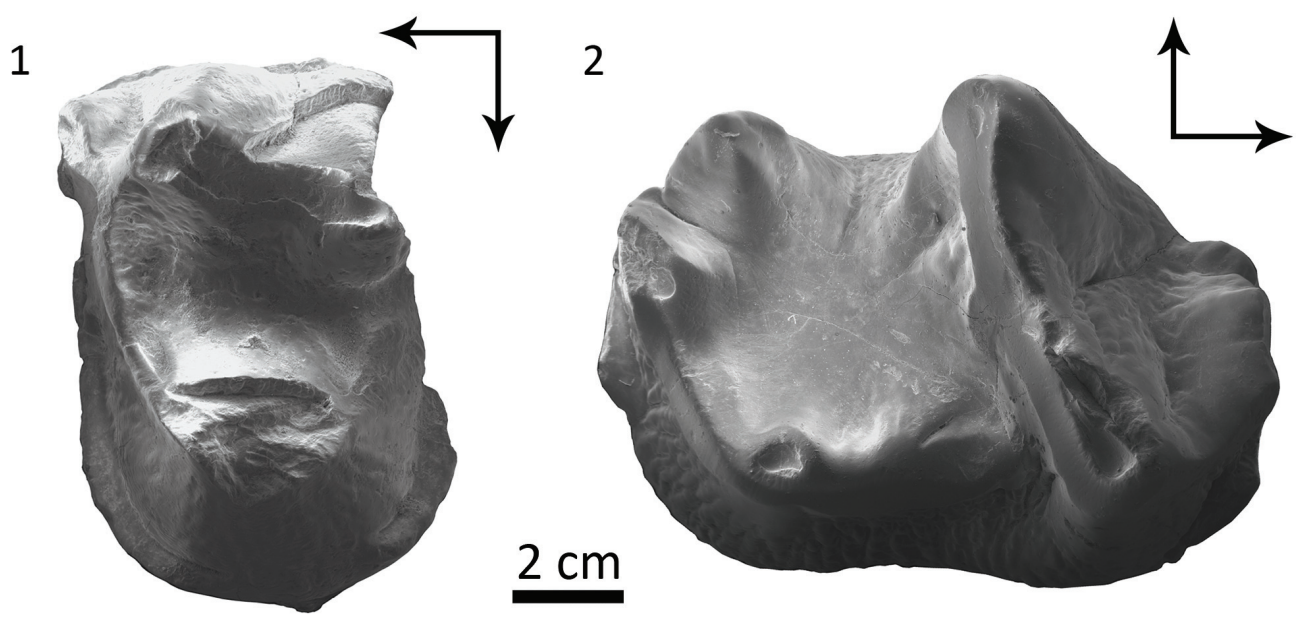

FIGURE 8. Trigonostylops wortmani Ameghino, 1897 from Cañadón Vaca. 1. MPEF PV 5482, left P4, in occlusal view; 2. MACN Pv CH1211, right m2, in occlusal view. Arrows indicate mesial and lingual sides.

onid involving distinct hypoconid/hypolophid and entoconid, as in Albertogaudrya. However, the premolars of MPEF PV 5477 are smaller (20-30\%) and comparatively lower crowned, the talonid of p3-p4 is shorter than the trigonid (inverse in Albertogaudrya, particularly in the p4), the labial flexid between protoconid and hypoconid is much more superficial, and lack labial cingulids. Compared with Trigonostylops and Tetragonostylops, both p3 and p4 have higher and more massive lophids and comparatively shorter talonids.

Remarks. Certainly, the distortion could have emphasized some of the traits of the mandible MPEF PV 5477 observed herein, as the extreme height of the symphysis and of the alveolus for the canine, but others seem to represent the original shape, such as the very upraised condition of this symphysis (not procumbent) and the posterior decreasing of the mandibular height. In any case, it is clear that the architecture of this mandible differs from that of Trigonostylops, Albertogaudrya, and more advanced astrapotheres. Similarly, the preserved cheek teeth do not match with those of the compared astrapotheres. Compared with the skull MPEF PV 5478 described above as cf. Scaglia cf. kraglievichorum, both belong to medium sized astrapotheres, larger than Trigonostylops and Tetragonostylops and smaller than Albertogaudrya. Nevertheless, the individual size of the premolars and the p2-p4 length of MPEF PV 5477 are somewhat larger (15-30\%, see Tables 2 and 3$)$ than their upper counterparts in MPEF PV 5478. In addition, MPEF PV 5477 has a comparatively large p2, nearly as large as the associated p3, whereas the
P2 of MPEF PV 5478 is significantly smaller than its corresponding P3. In all known Eocene astrapotheres, P2 and p2 are consistently smaller than their subsequent premolars, thus we conclude that the mandible MPEF PV 5477 and the skull MPEF PV 5478 more likely belong to distinct taxa.

Family TRIGONOSTYLOPIDAE Ameghino, 1901 Genus TRIGONOSTYLOPS Ameghino, 1897 Trigonostylops wortmani Ameghino, 1897 Figure 8

Referred materials. MACN Pv CH1211, isolated right m2; MPEF PV 5482, isolated left P4; MACN $\mathrm{Pv} \mathrm{CH} 1210$, isolated left P3.

Comparisons. The upper premolars MPEF PV 5482 (Figure 8.1) and MACN Pv CH1210 are simple, trigonodont teeth, essentially as in Trigonostylops and Tetragonostylops. However, both bear a minute but distinct metaconule, as seen in the P3 and P4 of Trigonostylops (Simpson, 1967), whereas this cuspule is indistinct in Tetragonostylops (Paula Couto, 1952, 1963). The lower molar MACN Pv CH1211 (Figure 8.2) agrees with those of Trigonostylops wortmani (e.g., MACN A 10627, Simpson 1967: fig. 2, 3) and differs from Tetragonostylops apthomasi in having lower and more transverse paracristid, and consequently mesiodistally shorter trigonid, and more distinct entoconid separated from the hypoconulid by a conspicuous distolabial notch.

Comments. Simpson $(1967 ; 2015)$ referred to Trigonostylops 4 isolated molars derived from Cañadón Vaca, but did not provide collection data. Cifelli (1985) listed Trigonostylops ?wortmani within 
his Vacan faunal list, likely from specimen of the Simpson's collections at the AMNH. The new specimens reported herein confirm the occurrence of Trigonostylops in the Vacan faunal association.

\section{DISCUSSION AND CONCLUSIONS}

The new astrapothere materials studied here confirm the occurrence of Trigonostylops and Tetragonostylops in the Cañadón Vaca assemblage. Tetragonostylops is represented by a partial skull and isolated upper molars, which are not comparable with the holotype of the only nominal species $T$. apthomasi, but likely belong to a species different from the more complete specimens described for the Itaboraí fauna by Paula-Couto (1952, 1963). The isolated M3 from Cañadón Vaca AMNH 28450, described by Simpson (1967, figure 49) as an indeterminate genus and species, and the isolated molar MACN Pv CH1248 reported by Soria (1982) as aff. T. apthomasi are herein referred to this species. A third taxon, herein described as cf. Scaglia cf. kraglievichorum, is represented by an adult skull, which could be co-specific with the juvenile skull of Scaglia kraglievichorum, also from Cañadón Vaca, described by Simpson (1957). An additional taxon would be represented by a peculiar mandibular fragment, described herein as Astrapotheriidae genus and species $\mathrm{A}$, which likely belong to a distinct taxon, but its co-specificity with $S$. kraglievichorum cannot be rejected with the available evidence.

Cifelli (1985) included Albertogaudrya (represented by an indeterminate species) in the Vacan faunal list, although with no references to inventory number of the specimens. It is noteworthy that Cifelli built his faunal lists based on the specimens collected by Simpson during the Scarritt Patagonian expeditions, but Simpson (1967) reported no specimen of Albertogaudrya from Cañadón Vaca. We could not confirm the occurrence of Albertogaudrya by the examination of old and new collections of Cañadón Vaca. We guess that the Vacan occurrence of Albertogaudrya proposed by Cifelli (1985) could be based on the isolated M3 AMNH 28450 mentioned above, which shows a cusps arrangement, especially the hypocone, similar to that observed in Scabellia, which in turn was interpreted by Simpson (1967) as a junior synonym of Albertogaudrya.

In sum, the astrapothere association of Cañadón Vaca is composed of at least three confirmed genera coexisting in the same deposits: Trigonostylops, Tetragonostylops, and Scaglia. If further findings confirm the occurrence of Albertogaudrya and that the mandible MPEF PV 5477 (genus and species A) belongs to a distinct genus, this would be the most diverse in terms of generic diversity for a single locality, exceeding the three genera identified for the early Miocene Lower Fossil Zone of the Sarmiento Formation at Gran Barranca (Kramarz and Bond, 2010). Comparing cranial, mandibular and dental measurements, Trigonostylops wortmani would have been similar in size to the modern collared peccary Tayassu tajacu (17-30 kg weight, Emmons and Feer, 1990), whereas Tetragonostylops aff. T. apthomasi would have been slightly smaller. The skull MPEF PV 5478 (cf. Scaglia cf. kraglievichorum) is almost as large as in the extant Tapirus terrestris (227-250 $\mathrm{kg}$, Emmons and Feer, 1990); the skull of juvenile Scaglia kraglievichorum (MMP M-207), with erupting M1, is also similar in size to a juvenile of $T$. terrestris with erupting $\mathrm{M} 1$. The partial mandible MPEF PV 5477 (Astrapotheriidae genus and species $A$ ), could have been somewhat larger than MPEF PV 5478. Albertogaudrya, although still unconfirmed in Cañadón Vaca, was the largest Casamayoran astrapothere; an estimate body mass calculated on the MACN A 12001, using the regression equation 3.265 Log (m1-m3 length)0.536 (Janis, 1990), suggests that Albertogaudrya was $500 \mathrm{~kg}$ weight, almost as large as a Sumatran rhino.

Following recent phylogenetic proposals (Cifelli, 1993; Kramarz and Bond 2009; Bond et al., 2011; Vallejo-Pareja et al., 2015), and assuming that Eoastrapostylops is not an astrapothere (Kramarz et al., 2017), Trigonostylops and Tetragonostylops are the earliest diverging astrapotheres known so far. The branching sequence is followed by Antarctodon, Albertogaudrya, and Scaglia, respectively. Antarctodon is only known from the early Eocene La Meseta Formation in western Antarctica (Bond et al., 2011). Although the occurrence of Albertogaudrya in Cañadón Vaca is still unconfirmed, phylogenetic reconstructions support that Albertogaudrya would have diverged from the lineage leading to advanced astrapotheres before Scaglia, and consequently it was already differentiated in Vacan times. In fact, a closely related taxon described as Albertogaudrya? carahuasensis by Carabajal et al. (1977) occurs in the lower Lumbrera Formation in NW Argentina, correlated to the Vacan subage (del Papa et al., 2010; Powell et al., 2011). Therefore, the four earliest diverging South American astrapotheres would have co-occurred during the Vacan times. 
Astrapotheres were traditionally characterized by having retracted nasals and, concomitantly a short, tapir like proboscis (e.g. Simpson, 1933; Rose, 2006). However, Soria and Bond (1984) reexamined specimens of Trigonostylops other than that described by Simpson (1933), concluding that they have long, unreduced nasals. The juvenile skull of Scaglia kraglievichorum similarly has long nasals, as already pointed out by Simpson (1957); and the same condition occurs in MPEF PV 5478 (cf. Scaglia cf. kraglievichorum), presumably an adult of Scaglia. The nasals are neither reduced in the skull of Tetragonostylops described above (Itaboraian specimens do not preserve the nasals). Consequently, all evidences indicate that all Casamayoran astrapotheres whose anterior part of the skull is known have unreduced nasals (skull of Albertogaudrya is still unknown). Astraponotus, from the Mustersan (late Eocene) fauna is the earliest astrapothere with retracted nasals (Kramarz et al., 2010). In Astraponotus, the reduction of the nasals is very extreme, essentially as in Astrapotherium and other late diverging astrapotheres, and no species with intermediate condition is known.

Dental features of Paleogene astrapotheres suggest a gradual evolution of increasing occlusal complexity, from the trigonodont molar pattern of
Trigonostylops to the typical astrapotheriid pattern already exhibited by Astraponotus (Simpson, 1967; Soria, 1988). In contrast, Eocene astrapotheres show a wide morphological disparity of cranial designs, with extremely autapomorphic cranial adaptations, as seen in the skull MPEF PV 5478 (cf. Scaglia cf. kraglievichorum). Oligocene and Miocene astrapotheres are more conservative, all showing essentially the same cranial architecture with minor variants respect to that of Astrapotherium.

\section{ACKNOWLEDGEMENTS}

To J. Flynn, J. Galkin (AMNH), and M. Taglioretti (MMP) for access to materials under their care. To G. Billet and an anonymous reviewer, for their thoughtful and helpful comments that significantly improved the quality of the manuscript. The artist Jorge Gonzalez made the schematic reconstruction of the skull of cf. Scaglia cf. kraglievichorum MPEF PV 5478. Field works in Cañadón Vaca were supported by grant from FONCyT to A.A.C. (PICT 3831-2016), and the research was partially financed by CONICET (PUE 22920160100098 to A.G.K).

\section{REFERENCES}

Ameghino, F. 1887. Enumeración sistemática de las especies de mamíferos fósiles coleccionados por Carlos Ameghino en los terrenos eocenos de Patagonia austral y depositados en el Museo de La Plata. Boletín del Museo de La Plata, 1:1-26.

Ameghino, F. 1894. Énumération synoptique des espèces de mammifères fossiles des formations éocènes de Patagonie. Boletín de la Academia Nacional de Ciencias en Córdoba, 13:259-455.

Ameghino, F. 1897. Les mammifères crétacés de l'Argentine. Deuxième contribution à la connaissance de la faune mammalogique des couches à Pyrotherium. Boletín del Instituto Geográfico Argentino, 18:406-521.

Ameghino, F. 1901. Notices préliminaries sur des ongulés nouveaux des terrains Crétacés de Patagonie. Boletín de la Academia Nacional de Ciencias en Córdoba, 16:1-349.

Bellosi, E.D. and Krause, J.M. 2014. Onset of the middle Eocene global cooling and expansion of open-vegetation habitats in central Patagonia. Andean Geology, 41:29-48. https://doi.org/ 10.5027/andgeov41n1-a02

Billet, G. 2010. New observations on the skull of Pyrotherium (Pyrotheria, Mammalia) and new phylogenetic hypotheses on South American ungulates. Journal of Mammalian Evolution, 17:21-59. https://doi.org/10.1007/s10914-009-9123-0

Billet, G., Muizon, C. de, Schellhorn, R., Ruf, I., Ladevèze, S., and Bergqvist, L. 2015. Petrosal and inner ear anatomy and allometry amongst specimens referred to Litopterna (Placentalia). Zoological Journal of the Linnean Society, 173:956-987. https://doi.org/10.1111/ zoj.12219 
Bond, M., Kramarz, A., MacPhee, R., and Reguero, M. 2011. A new astrapothere (Mammalia, Meridiungulata) from La Meseta Formation, Seymour (Marambio) Island, and a reassessment of previous records of Antarctic astrapotheres. American Museum Novitates, 3718:1-16. https://doi.org/10.1206/3718.2

Carrillo, J.D. and Asher, R.J. 2017. An exceptionally well-preserved skeleton of Thomashuxleya externa (Mammalia, Notoungulata), from the Eocene of Patagonia, Argentina.

Palaeontologia Electronica, 20.2.34A:1-33. https://doi.org/10.26879/759

palaeo-electronica.org/content/2017/1930-anatomy-and-systematics-of-thomashuxleyaexterna-notoungulata

Cifelli, R.L. 1985. Biostratigraphy of the Casamayoran, early Eocene, Patagonia. American Museum Novitates, 2820:1-26.

Cifelli, R.L. 1993. The phylogeny of the native South American ungulates, p. 195-216. In Szalay, F.S., Novacek, M.J., and McKenna, M.C. (eds.), Mammal Phylogeny Placentals. SpringerVerlag, New York.

del Papa, C.E., Kirschbaum, A., Powell, J.E., Brod, A., Hongn, F., and Pimentel, M. 2010. Sedimentological, geochemical and paleontological insights applied to continental omission surfaces: a new approach for reconstructing an Eocene foreland basin in NW Argentina. Journal of South American Earth Sciences, 29:327-345. https://doi.org/10.1016/ j.jsames.2009.06.004

Dunn, R.E., Strömberg, C.A.E., Madden, R.H., Kohn, M.J., and Carlini, A.A. 2015. Linked canopy, climate, and faunal change in the Cenozoic of Patagonia. Science, 347(6219):258261. https://doi.org/10.1126/science. 1260947

Emmons, L.H. and Feer, F. 1990. Neotropical Rainforest Mammals. A Field Guide. The University of Chicago Press, Chicago.

Janis, C.M. 1990. Correlation of cranial and dental variables with body size in ungulates and macropodoids, p. 255-300. In Damuth, J. and MacFadden, B.J. (eds.), Body Size in Mammalian Paleobiology: Estimation and Biological Implications. Cambridge University Press, Cambridge.

Janis, C.M. and Scott, K.M. 1987. The interrelationships of higher ruminant families with special emphasis on the members of the Cervoidea. American Museum Novitates, 2893:1-85.

Kramarz, A.G. and Bond, M. 2009. A new Oligocene astrapothere (Mammalia, Meridiungulata) from Patagonia and a new appraisal of astrapothere phylogeny. Journal of Systematic Paleontology, 7:117-128. https://doi.org/10.1017/s147720190800268x

Kramarz, A.G. and Bond, M. 2010. Colhuehuapian astrapotheriids (Mammalia) from Gran Barranca south of Lake Colhué Huapi, p. 182-192. In Madden, R., Carlini, A., Vucetich, M.G., and Kay, R. (eds.), The Paleontology of Gran Barranca: Evolution and Environmental Change through the Middle Cenozoic. Cambridge University Press, Cambridge.

Kramarz, A.G. and Bond, M. 2013. On the status of Isolophodon Roth (Mammalia, Astrapotheria) and other little-known Paleogene astrapotheres from central Patagonia. Geobios, 46:203211. https://doi.org/10.1016/j.geobios.2012.10.015

Kramarz, A.G., Bond, M., and Forasiepi, A. 2010. New remains of Astraponotus (Mammalia, Astrapotheria) and considerations on the astrapothere cranial evolution. Paläontologische Zeitschrift, 85:85-200. https://doi.org/10.1007/s12542-010-0087-4

Kramarz, A., Bond, M., and Rougier, G. 2017. Re-description of the auditory region of the putative basal astrapothere (Mammalia) Eoastrapostylops riolorense. Systematic and phylogenetic considerations. Annals of Carnegie Museum, 84:95-164. https://doi.org/ 10.2992/007.084.0204

Luo, Z. and Gingerich, P.D. 1999. Terrestrial Mesonychia to aquatic Cetacea: transformation of the basicranium and evolution of hearing in whales. University of Michigan Papers on Paleontology, 31:1-98.

Lydekker, R. 1894. Contribution to the knowledge of the fossil vertebrates of Argentina. 3. A study of extinct Argentine ungulates. Anales del Museo de La Plata, Paleontología Argentina, 2:1-91.

MacPhee, R.D.E. 2014. The serrialis bone, interparietals, "X" elements, entotympanics, and the composition of the notoungulate caudal cranium. Bulletin of the American Museum of Natural History, 384:1-69. https://doi.org/10.1206/384.1 
Muizon C. de, Billet, G., Argot, C., Ladevèze, S., and Goussard, F. 2015. Alcidedorbignya inopinata, a basal pantodont (Placentalia, Mammalia) from the early Palaeocene of Bolivia: anatomy, phylogeny and palaeobiology. Geodiversitas, 37:397-634. https://doi.org/10.5252/ g2015n4a1

O'Leary, M.A. 2010. An anatomical and phylogenetic study of the osteology of the petrosal of extant and extinct artiodactylans (Mammalia) and relatives. Bulletin of the American Museum of Natural History, 335:1-206. https://doi.org/10.1206/335.1

O'Leary, M.A. and Gatesy, J. 2008. Impact of increased character sampling on the phylogeny of Cetartiodactyla (Mammalia): combined analysis including fossils. Cladistics, 24:397-442. https://doi.org/10.1111/j.1096-0031.2007.00187.x

Paula-Couto, C. 1952. Fossil mammals from the beginning of the Cenozoic in Brazil. Bulletin of the American Museum of Natural History, 99:359-394.

Paula-Couto, C. 1963. Um Trigonostylopidae do Paleoceno de Brazil. Anais Academia Brasileira de Ciências, 35:339-351.

Powell, J.E., Babot, M.J., García López, D.A., Deraco, M.V., and Herrera, C.M. 2011. Eocene vertebrates of northwestern Argentina: annotated list, p. 349-370. In Salfity, J.A. and Marquillas, R.A. (eds.), Cenozoic Geology of the Central Andes of Argentina. SCS Publisher, Salta.

Price, L.I. and Paula-Couto, C. 1950. Vertebrados terrestres do Eoceno na bacia calcárea de Itaborai. Anais II Congresso Panamericano de Engenharia de Minas e Geologia, 3:149-173.

Rose, K.D. 2006. The Beginning of the Age of Mammals. The Johns Hopkins University Press, Baltimore.

Scott, W.B. 1937. The Astrapotheria. Proceedings of the American Philosophical Society, 77:309-393, pls. 1-9.

Simpson, G.G. 1930. Scarritt-Patagonian Expedition Field Notes, Book 1. http:// research.amnh.org/paleontology/notebooks/simpson-1930a/

Simpson, G.G. 1933. Structure and affinities of Trigonostylops. American Museum Novitates, 608:1-28.

Simpson, G.G. 1935a. Descriptions of the oldest known South American mammals, from the Rio Chico formation. American Museum Novitates, 793:1-25

Simpson, G.G. 1935b. Occurrence and relationships of the Río Chico fauna of Patagonia. American Museum Novitates, 818:1-21

Simpson, G.G. 1957. A new Casamayoran astrapothere. Revista del Museo de Ciencias Naturales y Tradicionales de Mar del Plata, 1:149-173.

Simpson, G.G. 1967. The beginning of the Age of mammals in South America. Part 2. Bulletin of the American Museum of Natural History, 137:1-259, plates 1-46.

Soria, M.F. 1982. Tetragonostylops apthomasi (Price y Paula-Couto, 1950): su asignación a Astrapotheriidae (Mammalia; Astrapotheria). Ameghiniana, 19:234-238.

Soria, M.F. 1988. Estudios sobre los Astrapotheria (Mammalia) del Paleoceno y Eoceno. Parte II: Filogenia, origen y relaciones. Ameghiniana, 25:47-59.

Soria, M.F. and Bond, M. 1984. Adiciones al conocimiento de Trigonostylops Ameghino, 1897 (Mammalia, Astrapotheria, Trigonostylopidae). Ameghiniana, 21:43-51.

Vallejo-Pareja, M.C., Carrillo, J.D., Moreno-Bernal, J.W., Pardo-Jaramillo, M., RodriguezGonzalez, D.F., and Muñoz-Durán, J. 2015. Hilarcotherium castanedaii, gen. et sp. nov., a New Miocene Astrapothere (Mammalia, Astrapotheriidae) from the Upper Magdalena Valley, Colombia. Journal of Vertebrate Paleontology, 35:e903960. https://doi.org/10.1080/ 02724634.2014.903960

Welker, F., Collins, M.J., Thomas, J.A., Wadsley, M., Brace, S., Cappellini, E., Turvey, S.T., Reguero, M., Gelfo, J.N., Kramarz, A., Burger, J., Thomas-Oates, J., Ashford, D.A., Ashton, P.D., Rowsell, K., Porter, D.M., Kessler, B., Fischer, R., Baessmann, C., Kaspar, S., Olsen, J.V., Kiley, P., Elliott, J.A., Kelstrup, C.D., Mullin, V., Hofreiter, M., Willerslev, E., Hublin, J.J., Orlando, L., Barnes, I., and MacPhee, R.D.E. 2015. Ancient proteins resolve the evolutionary history of Darwin's South American ungulates. Nature, 522:81-84. https://doi.org/10.1038/ nature14249

Woodburne, M.O., Goin, F.J., Bond, M., Carlini, A., Gelfo, J., López, G., Iglesias, I., and Zimicz, N. 2014. Paleogene Land Mammal faunas of South America; a response to global climatic changes and indigenous floral diversity. Journal of Mammalian Evolution, 21:1-73. https:// doi.org/10.1007/s10914-012-9222-1 


\section{APPENDIX 1}

\section{List of specimens used for comparisons}

Tayassu tajacu: MACN Ma 25.57, 45.20, 50.131, 45.27, 47.379, 24.926, 50.130, 48.23, 49.329, $23.725,36.697$

Tapirus terrestris: MACN Ma 4.339, 24.30, 27200, 52.77, 19.147

Trigonostylops wortmani: AMNH 28700, MLP 52-X-5-98, MACN Pv 47 (cast of MNHN.F.CAS 187), MACN A 10627, 10629, 10651, 10900.

Tetragonostylops apthomasi: DGM 355-M, AMNH 49831, 49832, 49836, 49854, 49838, 49839, 49861, 49862, 49863, MLP 69-I-9-8.

Albertogaudrya unica: MACN A 10634, 10635, 12000, 12002, 12004, 12005, 12007, 12008, 12014, AMNH 28639, 28640, 28641, 28947.

Astraponotus spp.: MACN A 10971, MLP 12-1471, 12-2217, 67-II-27-28, 67-II-27-379, 67-II-27167, 83-III-3-1, 82-V-7-2, 69-III-24-295, MPEF PV 1084, 1279, 1296,

Astrapotherium magnum: AMNH 9278, FMNH 13170, 14251, YPM PU 15261, 15332, MACN A 3208, 8580.

Parastrapotherium spp.: MACN A 52-604, AMNH 29596, 29575, FMNH 13329, 13413.

Granastrapotherium snorki: IGM SCG-MGJRG-2018 V4 